\title{
EL VOTO POR CORREO: ¿UNA NUEVA REFORMA?
}

\author{
LUIS GÁLVEZ MUÑOZ
}




\section{SUMARIO}

1. INTRODUCCIÓN. 2. EL MARCO TEÓRICO DEL VOTO POR CORREO. A) FUNDAMENTO Constitudional. B) Carácter contingente. C) Principios informadores. 3. LA REgULACIÓN DEL VOTO POR CORREO EN ESPAÑA. A) SUPUESTOS EN QUE PROcede. B) Procedimiento. a) Procedimiento ordinario. b) Procedimientos ESPECIALES. C) RÉgIMEN SANCIONADOR. 4. ConsideraCiones finales Y PROPUESTAS DE REFORMA. 


\title{
EL VOTO POR CORREO: ¿UNA NUEVA REFORMA?
}

\author{
POR \\ LUIS GÁLVEZ MUÑOZ \\ Profesor de Derecho Constitucional \\ Universidad de Murcia
}

\section{INTRODUCCIÓN}

La modificación de la legislación electoral es un tema que aparece de modo recurrente y periódico en todos los países democráticos del mundo. Basta que aparezca un problema en un proceso electoral concreto, que una fuerza política no cumpla las expectativas de poder que se había marcado o que se observen deficiencias en el funcionamiento del sistema político, para que prenda la mecha que abre, con más o menos intensidad y extensión, la discusión sobre la necesidad o no de reformar las reglas que han encauzado la competición electoral.

España no es, desde luego, una excepción a este estado de cosas. Desde la restauración de las libertades en nuestro país en la segunda parte de la década de los años setenta del pasado siglo, los políticos, los científicos sociales, los juristas, los articulistas de prensa e incluso la propia opinión pública, no han dejado de interesarse nunca -y especialmente al hilo de los distintos procesos electorales celebrados- por la posibilidad de introducir reformas en los más diversos elementos que integran el régimen electoral. Se dedicaron a ello con entusiasmo desbordante durante la vigencia del Real Decreto Ley 20/1977, de 18 de marzo, sobre Normas Electorales, y lo siguen haciendo ahora, aunque de forma más serena y desapasionada, con la 
que la sustituye, la Ley Orgánica 5/1985, de 19 de junio, del Régimen Electoral General (en adelante, LOREG).

Nos encontramos, pues, ante un sector normativo que es constantemente criticado y cuestionado, es decir, sobre el que nunca termina de darse el último vistazo que permite concluir su diseño y archivar el resultado obtenido ${ }^{1}$. Se puede decir, por ello, que el tema de la reforma electoral es casi consustancial a nuestra democracia y que incluso ha llegado a formar parte del propio rito de las elecciones, tal y como han puesto agudamente de manifiesto José R. Montero $y$ Josep M. ${ }^{\text {a Vallés: }}$

"Si todos los procesos electorales generan sus propios ritos, da la impresión de que en España uno de los más fascinantes para los observadores políticos, los medios de comunicación y buena parte de las elites partidistas consiste en solicitar la reforma del sistema electoral» 2 .

$Y$ esto no es en absoluto negativo. Es bueno que sea así. La existencia de críticas y propuestas de modificación del régimen electoral no es algo anómalo o disfuncional, expresivo de una grave patología de nuestra democracia. Todo lo contrario. Demuestra una fina sensibilidad democrática y un alto nivel de exigencia en nuestra sociedad sobre la articulación y el funcionamiento del sistema político y, en última instancia, sobre la legitimidad del poder, pues no debemos olvidar nunca que el proceso electoral es el vehículo fundamental mediante el que el pueblo soberano se expresa y se hace presente en las instituciones.

El sistema democrático lejos de debilitarse, por tanto, con el debate y cuestionamiento de las reglas electorales, se fortalece; se aproxima a los problemas latentes de la vertebración de la participación política electoral y adquiere horizontes de renovación en pro de su mejor funcionamiento. En este sentido es útil que tomemos prestadas las palabras que en 1986 pronunciara el diputado popular Miguel Herrero Rodríguez de Miñón en el Congreso de los Diputados, aunque en relación con un tema muy distinto al de las elecciones:

"Las instituciones democráticas se fortalecen cuando se las exige, cuando se las pone a prueba, no cuando se tiene tanto miedo de tocarlas que incluso se es incapaz de exigirlas todo rigor. Hay un dicho popular que

1 En este sentido José R. ÓNEGA LÓPEZ ha hablado del Derecho electoral como Derecho esencialmente crítico, en el más amplio sentido del término. Vid. Prólogo del libro de Pablo SANTOLAYA MACHETII, Manual de procedimiento electoral, cuarta edición, Ministerio del Interior-Secretaria General Técnica, Madrid, 1999, pág. 16.

2 Vid. José R. MonTERo y Josep M. VALLÉs, «El debate sobre la reforma electoral. ¿Para qué las reformas?", Claves de la Razón Práctica, núm. 22, 1992, pág. 2. 
dice que el fuego purifica el oro y endurece el barro. Pues bien, nosotros creemos que con la democracia, con la democracia madura que tenemos que tener en España, que es una sociedad occidental y europea de fines del siglo $\mathrm{XX}$, que efectivamente no es ninguna república bananera, es una democracia madura y un pueblo maduro... Pues bien, con la democracia española hay que hacer como para purificar el oro, exigirla y los que de verdad confiamos -y estoy seguro que todos en esta Cámara confiamos de la democracia española-, sabemos que no es barro y no corre peligro porque se le aplique la prueba de la exigencia $y$ del rigor» 3.

Ahora bien, cuestión distinta a la de la oportunidad del debate sobre la regulación electoral es la de sus posibilidades de éxito, es decir, que la discusión y articulación de propuestas de reforma tenga posibilidades reales de traducirse en modificaciones concretas que supongan una mejora constatable del régimen electoral y, en definitiva, de la capacidad de las elecciones para cumplir sus funciones esenciales: producir representación, generar gobierno y ofrecer legitimidad 4.

$Y$ en este sentido la respuesta tiene que ser necesariamente ambivalente, pues si de un lado ha habido ya numerosas reformas de la LOREG -nueve hasta el momento ${ }^{5}$ - sobre las que no cabe duda de que, en conjunto, han producido una notable mejora de su diseño; de otro lado, hay que tener en cuenta que todas las modificaciones llevadas a cabo se han concentrado en uno solo de los dos grandes bloques de que consta el Derecho electoral: el procedimiento electoral, quedando intocados los distintos elementos que integran el otro sector de esta regulación, el sistema electoral.

¿Y por qué este desequilibrio tan considerable entre estas dos partes del Derecho electoral? Ello se debe seguramente a múltiples y muy distintas razones, pero a nuestro juicio fundamentalmente a las dos siguientes.

3 Vid. Diario de Sesiones del Congreso de los Diputados, II Legislatura, Pleno, núm. 274, de 28 de febrero de 1986, págs. 12353-12354.

4 La función de las elecciones ha sido tratada admirablemente por Francesc de Carreras y Josep M. ${ }^{a}$ Vallés, Las elecciones. Introducción a los sistemas electorales, Blume, Barcelona, 1977, págs. 17-32; y Josep M." VALLÉs y Agustí BosCH, Sistemas electorales y gobierno representativo, Barcelona, Ariel, 1997, págs. 16-28. Vid. también María Vicenta García SoRIANo, Elementos de Derecho electoral, Tirant Lo Blanch, Valencia, 1999, págs. 15-19.

5 La Ley Orgánica 5/1985, de 19 de Junio, del Régimen Electoral General, ha sido modificada por las Leyes Orgánicas 1/1987, de 2 de abril; 8/1991, de 13 de marzo; 6/1992, de 2 de noviembre; 13/1994, de 30 de marzo; 3/1995, de 15 de junio; 10/1995, de 23 de noviembre; 1/1997, de 13 de marzo; 3/1998, de 15 de junio; $y$ 8/1999, de 21 de abril. 
a) En primer lugar, hay que aludir a la distinta relevancia institucional y social que tienen los problemas y deficiencias que eventualmente se detecten en uno y otro ámbito. Las críticas sobre la mayor o menor proporcionalidad de la fórmula electoral utilizada, la adecuación de la circunscripción elegida como base de la elección o el amplio o reducido margen de libertad de que disfruta el elector en la confección de su papeleta electoral, entran dentro de la discusión política y operan y se aceptan por todos como opciones electorales legítimas. Sin embargo, el reproche a la integridad del censo electoral, la neutralidad y eficacia de la Administración Electoral, la autenticidad del voto por correo o la veracidad del recuento de los votos son cuestiones que afectan a la propia esencia y pureza de las elecciones, por lo que si se les pone en duda, se pone también en cuestión la legitimidad del propio resultado de las elecciones.

Lo diremos con palabras de Pablo Santolaya Machetti, uno de los autores que con mayor rigor, detenimiento y perspectiva de conjunto se ha ocupado del estudio del procedimiento electoral:

«Dando un paso más puede incluso afirmarse que las críticas al sistema electoral son o suelen ser perfectamente asimilables sin merma de representatividad ni de legitimidad; así se puede discutir sobre el mayor o menor grado de proporcionalidad del sistema, la adecuación de una u otra fórmula matemática de conversión de sufragios atendiendo a una mayor o menor justicia, sobre las ventajas o desventajas del voto bloqueado. Nada de ello incide sin embargo de forma grave en la esencia misma del sistema, su capacidad de generar legitimación. Se acepta incluso de forma universal que la mediación característica de los sistemas electorales no es neutral ni químicamente pura, sino que suele favorecer a los partidos mayoritarios, que son, no lo olvidemos, los que hacen las leyes electorales. No ocurre lo mismo con las críticas a los procedimientos electorales; una normativa electoral no puede sobrevivir si sobre ella se lanzan constantes dudas sobre la corrección del censo, el escrutinio en las mesas o el voto por correo, ya que entonces lo que se pone en duda es la limpieza misma del proceso, su carácter democrático y representativo" 6 .

6 Vid. Pablo Santolaya Machetti, Manual de procedimiento electoral, cuarta edición, Ministerio del Interior-Secretaría General Técnica, Madrid, 1999, pág. 38 (asimismo lo recoge en su artículo "La crisis del procedimiento electoral español", en Fernando SAINZ Moreno (coordinador), IV Jornadas de Derecho Parlamentario. Reflexiones sobre el régimen electoral. Enero 1993, Congreso de los Diputados, Madrid, 1997, págs. 446-447). También podríamos haber traído de forma más sintética la cita de José Ortega y Gasset que hace Enrique ARNALDo ALCUBILLA en su magnífico libro El derecho de sufragio de los emigrantes en el ordenamiento español, Centro de Estudios Constitucionales, Madrid, 1995, pág. 104: "La salud de 
b) El segundo argumento tiene un carácter más pedestre y particular. Se trata pura y simplemente de poner de manifiesto que mientras no existen razones de interés partidista para contener y evitar la reforma del procedimiento electoral, sí las hay y de gran calado -por parte de las fuerzas mayoritarias- para impedir cualquier cambio en los distintos elementos que integran el sistema electoral.

Como se ha puesto de manifiesto en tantas ocasiones por múltiples autores, el sistema electoral diseñado en la LOREG -que prácticamente es idéntico al del Real Decreto Ley 20/1977- beneficia claramente a las fuerzas políticas mayoritarias a nivel estatal y territorial, ya que obtienen, en mayor o menor medida, un porcentaje superior de escaños que el que les correspondería proporcionalmente en relación con el número de sufragios populares obtenidos. $Y$ como estas fuerzas políticas son las únicas que están en condiciones de accionar la llave de la reforma, es evidente que la misma difícilmente se va a poner en marcha alguna vez, pues nadie está interesado en sustituir una pieza que le beneficia claramente por otra que posiblemente le perjudique. José R. Montero y Josep M. ${ }^{a}$ Vallés lo han expresado así:

«El siempre recurrente y en ocasiones apasionado debate sobre la reforma del sistema electoral se traduce raramente en cambios sustanciales. De hecho, un análisis de la evolución de los sistemas electorales en los países europeos ha revelado que los cambios fundamentales se produjeron hace unos 50 años, y que desde entonces la regla general ha consistido en la adopción de modificaciones menores que no alteran los elementos definitorios de cada sistema. Su considerable resistencia a los cambios ha hecho que la mayor parte de las propuestas -sobre todo cuando afectan a los aspectos básicos del esquema- queden aparcadas en el campo del debate teórico. Es fácil entenderlo. La elaboración y reforma de un sistema electoral no es obra de técnicos o expertos que crean el mejor sistema. Se trata, por definición, de una decisión política, adoptada por políticos y en función de intereses políticos: los criterios académicos, las soluciones teóricas o los refinamientos técnicos no suelen tener más peso que el que quiera otorgárseles por quienes deciden y para legitimar su decisión. Pero se trata, además, de una decisión que habitualmente toman los políticos elegidos por el mismo sistema electoral que pretende reforamarse. No es estraño, por tanto, que quienes se han beneficiado de un determinado sistema se opongan, con mayor o menor contundencia, a la adopción de alteracio-

las democracias, cualesquiera que sea su tipo y grado, depende de un mísero detalle técnico: el procedimiento electoral. Todo lo demás es secundario" (La rebelión de las masas, segunda parte, capítulo XIV, en Obras completas, tomo IV, Alianza Editorial y Revista de Occidente, Madrid, 1983, pág. 255). 
nes que acaso les perjudiquen en las próximas elecciones, y tampoco puede sorprender que se manifiesten reticentes $y$ escépticos ante posibles cambios, aunque les prometan unos siempre eventuales e inciertos beneficios futuros" 7 .

Toda esta larga digresión sobre la mayor o menor utilidad de la realización de propuestas de reforma en materia electoral ha tenido un único y claro objetivo: poner de relieve la gran importancia práctica que revisten las cuestiones relativas al procedimiento electoral, habitualmente menospreciadas con los apelativos de "burocráticas", "adjetivas" y "secundarias" 8 y escasamente tratadas por la doctrina constitucional ${ }^{9}$, encandilada ante el amplio $y$, sin duda, apasionante campo de maniobra política que ofrecen las distintas piezas del sistema electoral y los relevantes efectos que tienen sobre muy diversos aspectos del sistema político: mayor o menor número de partidos, favorecimiento o penalización de fuerzas nacionalistas territoriales, disciplina partidista o propiciación de personalismos, fomento o no de mayorías absolutas... ${ }^{10}$

$Y$ es precisamente el relevante interés práctico que tiene el procedimiento electoral, lo que motiva de manera fundamental el que ahora nos vayamos a ocupar de su estudio, alejándonos prudentemente del evidente riesgo de ejercicio melancólico que tiene, a nuestro juicio, adentrarse en las quietas y concurridas aguas del análisis del sistema electoral. Ahora bien, por comprensibles razones de oportunidad y espacio no pretendemos realizar en este lugar el estudio completo del mismo, sino que sólo nos vamos a ocupar de una de sus piezas más relevantes y polémicas: el voto por correo ${ }^{11}$.

7 Vid. José R. Montero y Josep M. vallÉs, «El debate...", op. cit., pág. 2. Vid. también Enrique ARNALDo AlCUBILLA El derecho de...., op. cit., págs. 289-297; y Pablo Santolaya Machetti, Manual de..., op. cit., págs. 31-36.

8 Vid. Pablo Santolaya Machetti, Manual de..., op. cit., pág. 38.

9 Una muy útil bibliografía de Derecho electoral se encuentra en Enrique Arnaldo Alcubilla, El régimen electoral de España, Centro de Estudios Políticos y Constitucionales y Boletín Oficial del Estado, Madrid, 1999, págs. 43-89.

10 Sobre la imbricación entre sistema electoral y sistema político vid. Maurice DUVERger, L'influence des systèmes electoraux sur lea vie politique, A. Colin, París, 1957; Josep M. . VALLÉs y Agustí BosCH, Sistemas electorales..., op. cit., especialmente págs. 115-251; Francesc PALLARÉs PORTA, "Sistema electoral y sistema de partidos", Parlamento y sistema electoral. VI Jornadas de la Asociación Española de Letrados de Parlamentos, Aranzadi, Pamplona, 1999, págs. 61-83.

11 En otras ocasiones nos hemos ocupado de otros aspectos del procedimiento electoral; en concreto de la Administración electoral y de las encuestas electorales. Vid. Luis GÁLVEZ MUÑOZ, "La prohibición de publicar encuestas electorales: ¿una norma inconstitucional?», Revista de las Cortes Generales, núm. 41, 1997, 
Este procedimiento de votación está regulado actualmente en la LOREG (artículos 72 a 75, 139, 141 y 190) y en diversas disposiciones complementarias, (fundamentalmente el Real Decreto 605/1999, de 16 de abril, de regulación complementaria de los procesos electorales), aunque se halla presente en nuestro Derecho desde hace bastantes años: lo contempló la legislación electoral de la transición (el Real Decreto Ley 20/1977, de 18 de marzo sobre normas electorales, la Ley 39/1978, de 17 de julio, de elecciones locales, etc.) 12, y antes incluso el régimen franquista con el Decreto 1796/1967, de 20 de julio, por el que se dictan normas complementarias de la Ley de Representación Familiar en Cortes ${ }^{13}$.

No obstante, ha sido durante la última década del siglo XX cuando ha alcanzado cierta notoriedad. El voto por correo lleva dando, ciertamente, mucho que hablar desde los fraudes perpetrados con ocasión de las elecciones locales y autonómicas de mayo de 1991: ha dado lugar a varias Sentencias del Tribunal Constitucional y del Tribunal Supremo y de otros órganos de la jurisdicción ordinaria 14 , ha originado un informe específico y diversas resoluciones e instrucciones de la Junta Electoral Central ${ }^{15}$, ha resultado

págs. 45-89; "La independencia de la Junta Electoral Central y sus garantías", en VV.AA., Parlamento y sistema electoral. VI Jornadas de la Asociación Española de Letrados de Parlamentos, Aranzadi, Pamplona, 1999, págs. 97-117; "Organismos de sondeos, encuestas electorales y Derecho", Revista de Estudios Políticos, núm. 110, octubre-diciembre 2000, págs. 97-121; y El régimen jurídico de la publicación de las encuestas electorales, Congreso de los Diputados, Madrid, 2001.

12 Vid. el artículo 57 del Real Decreto Ley 20/1977; la Disposición Final Tercera de la Ley 39/1978; el Real Decreto 2120/1978, de 25 de agosto, por el que se establecen normas para la celebración de consulta directa a la nación por medio de referéndum en relación a la Constitución aprobada por las Cortes Generales; el Real Decreto $80 / 1979$, de 5 de enero, sobre ejercicio del derecho de voto de los emigrantes inscritos en el CERA en las elecciones locales; etc.

13 Vid. el artículo 23 de este Decreto de 1967 y otras normas complementarias. Por ejemplo, la Orden del Ministerio de Gobernación de 12 de septiembre de 1967 por la que se dictan instrucciones para el desarrollo de la labor que el Servicio de Correos debe llevar a cabo en las elecciones convocadas a Procuradores en Cortes de las distintas representaciones y a Consejeros Nacionales del Movimiento (artículo 5).

14 Vid., por ejemplo, las Sentencias del Tribunal Constitucional 180/1988, de 11 de octubre y 169/1991, de 19 de julio.

15 . Sobre las resoluciones y acuerdos de la Junta Electoral Central vid. Enrique Arnaldo Alcubilla y Manuel Delgado-Iribarren Garcia-Campero, Código electoral, 3. ${ }^{a}$ edición, Abella, Madrid, 1999, vol. I, págs. 382 y ss. El informe de la Junta sobre el voto por correo, emitido el 10 de abril de 1992, no ha sido, sin embargo, publicado. 
afectado por dos reformas de la LOREG 16 , ha suscitado numerosas intervenciones, propuestas y debates en el Parlamento ${ }^{17}$ y ha originado $-y$ esto es lo más importante- un fuerte debate político y social sobre su justificación y el riesgo que entraña de fraude en las elecciones ${ }^{18}$.

En resumidas cuentas, se puede decir que el voto por correo ni ha pasado desapercibido en los últimos años, ni ha terminado tampoco de encontrar su sitio definitivo en nuestro ordenamiento electoral. $Y$ en este último punto reside nuestro interés actual por el tema: determinar si es o no necesario proceder a su reforma y, en su caso, en qué sentido habría que llevarla a cabo. De su estudio nos vamos a ocupar brevemente -y sin más demora- a continuación, de acuerdo con el siguiente esquema de desarrollo:

- En primer lugar, vamos a tratar de situar el voto por correo en su marco teórico: justificación constitucional, carácter de su reconocimiento legal, principios informadores.

- En segundo término, nos centraremos en el examen de la vigente regulación del voto por correo que contiene la LOREG: supuestos en que procede, forma de organizarse, régimen sancionador establecido en garantía de su cumplimiento.

- Finalmente, y a la luz de la integración de los apartados anteriores, expondremos las conclusiones y, en su caso, las propuestas de reforma que nos parezcan oportunas llevar a cabo.

16 Se trata de las reformas de la LOREG efectuadas por las leyes orgánicas 6/1992, de 2 de noviembre; y 3/1995, de 15 de junio, aunque esta última incidió muy levemente sobre el voto por correo.

17 Vid. por ejemplo la moción recientemente aprobada por el Pleno del Congreso de los Diputados por la que se insta al Gobierno a remitir un Proyecto de modificación de la LOREG en relación con el ejercicio del derecho de sufragio activo de los españoles en el exterior inscritos en el censo de residentes ausentes (Boletín Oficial de las Cortes Generales. Senado, Serie I, núm. 205, 29 de mayo de 2001, págs. 15-16).

18 El origen fundamental de este debate se encuentra en los fraudes organizados por determinados miembros de cierto partido político en las elecciones autonómicas y locales de 1991, y que dieron lugar a numerosas resoluciones tanto de tribunales penales como contencioso-administrativos (en la resolución de recursos contencioso-electorales). 


\section{EL MARCO TEÓRICO DEL VOTO POR CORREO}

\section{A) Fundamento constitucional}

El voto por correspondencia está previsto y regulado en la LOREG, pero tiene su fundamento en la Constitución, pues con el reconocimiento de esta modalidad de votación no se pretende otra cosa que facilitar el ejercicio de uno de los más relevantes derechos fundamentales: el derecho de sufragio, reconocido en el artículo 23.1 de nuestra Ley Fundamental. Con el voto por correo se trata de hacer posible la expresión del sufragio por parte de todos aquellos electores que, por las razones que fuere, no pueden acercarse a su Mesa de votación el día de las elecciones.

El anclaje o engarce constitucional de esta forma de votación es, pues bastante evidente. No obstante, no parece en absoluto improcedente, sino todo lo contrario, detenernos un momento en su examen, pues la importancia del tema tratado así parece exigirlo. A este respecto son tres las consideraciones que parece necesario hilvanar.

a) En primer lugar hay que tener en cuenta la gran relevancia institucional que tiene el ejercicio del derecho de sufragio, pues sobre el mismo descansa todo el edificio constitucional. La expresión del voto permite materializar el principio democrático que se consagra solemnemente en el artículo 1.2 de la Constitución. Si los ciudadanos no depositan su voto en las urnas el día de la celebración de la votación o si son muy pocos los que lo hacen no hay democracia que valga, pues no se produciria una legitimación efectiva del poder 19.

La participación electoral tiene así un extraordinario valor objetivo en sí mismo. El sufragio se configura no sólo como un derecho subjetivo individual, de gran importancia para el completo desarrollo de la libertad y la dignidad de la persona, sino también como un derecho que tiene un extraordinario valor para la comunidad, pues cumple una función legitimadora imprescindible para el funcionamiento de la democracia; dicho de otra forma: con la expresión del sufragio el ciudadano ejerce su derecho a votar, pero también contribuye a la formación de la voluntad estatal y al correcto funcionamiento del Estado democrático.

19 El tema de la abstención es, no obstante, bastante polémico. Vid. por ejemplo, Herbert MCCLoskY, "Participación Política», en David S. SILLS (director), Enciclopedia Internacional de las Ciencias Sociales, vol. 7, Aguilar, 1975, págs. 633635. Vid. también la Sentencia del Tribunal Constitucional 208/1989, de 14 de diciembre. 
Esto explica que se haya podido llegar a hablar del ejercicio del derecho de voto como expresión de un "deber ético" o "moral». EI ciudadano que vota no se limita a hacer uso de su derecho fundamental al sufragio, sino que va un poco más allá: da cumplimiento a una obligación ciudadana inexcusable de carácter cívico o social, aunque sin llegar a alcanzar naturaleza jurídica, pues ello iría, lógicamente, en contra de la libertad ideológica consagrada en el artículo 16 de la Constitución 20 . Lo diremos con las palabras del Tribunal Supremo:

"El sufragio se construye desde la perspectiva del sujeto como derecho, pero con un claro talante de función pública, conectado en su raíz al pluralismo social y político propio de un sistema democrático, que se refleja a su vez en los partidos políticos como cauce de la formación y manifestación de la voluntad popular e instrumento fundamental para la participación política (arts. 1.ำ $6 . \%$ ). Una acepción aún más profunda, nos muestra el voto como la expresión genuina e insustituible de la soberanía nacional. En definitiva, el concepto de función conlleva que el derecho de sufragio presente a su vez como reverso su aspecto de obligación ciudadana, sobre cuyo ejercicio descansa la entera arquitectura del sistema democrático. En tal significado, resulta genéricamente «inexcusable», aun cuando pueda ser excusado a título individual... La calificación como deber pone de manifiesto su trasfondo ético, más aún que jurídico y explica que el incumplimiento, que puede ser también una forma de expresión política mediante la abstención (a veces recomendada por los partidos, como concretamente ocurrió en esa ocasión), no conlleva una consecuencia perjudicial para su autor, una sanción en el sentido amplio del vocablo, no en el más riguroso de respuesta represiva. En tal aspecto las normas reguladoras del procedimiento para las elecciones son "imperfectas", en una terminología jurídica tradicional, hoy obsoleta. En definitiva, esta calificación del sufragio como derecho y deber, cara y cruz de la función que le está asignada, no es sino el reconocimiento de una realidad a la cual sirven de vestidura las categorías jurídicas» 21.

20 Sobre la naturaleza del derecho de sufragio (derecho, deber o función) vid. Paolo BIscaretTI DI Ruffia, Derecho Constitucional, tercera edición, Tecnos, Madrid, 1987, págs. 306-308; Luis LóPEZ GueRRA, "Tema 14. Derechos de participación política", en VV.AA., Derecho Constitucional, vol. I, págs. 322-323; y Eduardo ESPIN TEMPLADO, "Desarrollo y resultado de la elección", en VV.AA., El proceso electoral, Labor, Barcelona, 1977, págs. 125-128.

21 Se trata de la famosa Sentencia del Tribunal Supremo de 20 de diciembre de 1990 (Orden Contencioso-Administrativo) emitida por la Sala Especial de Revisión prevista en el artículo 61 de la Ley Orgánica del Poder Judicial, y en virtud de la cual se resolvió definitivamente el tema de la constitucionalidad y legalidad de los permisos retribuidos para votar. 
b) La segunda consideración que queremos realizar hace referencia a la genérica obligación que tienen los poderes públicos de facilitar el ejercicio del derecho de sufragio por parte de todos los electores. El Estado, entendiendo este término en su sentido más amplio, está constitucionalmente obligado a hacer todo lo posible para que la participación electoral de la ciudadanía pueda ser una realidad efectiva y tangible, de tal modo que el derecho de voto pueda encontrar su realización plena, inmanente a su carácter universal 22.

Los poderes públicos están obligados ex-constitutione a facilitar el ejercicio de los distintos derechos fundamentales, pero esta obligación es particularmente exigible en el caso del derecho de sufragio dada la gran importancia que, como hemos visto, tiene el mismo en nuestro sistema político. Si este derecho constituye la piedra angular de la democracia representativa en que vivimos, es claro que el Estado no puede permanecer indiferente ante su ejercicio. Muy al contrario. Debe utilizar todos los medios a su alcance para poder conseguir que la mayor parte de los ciudadanos, si no todos, hagan uso de su derecho fundamental al sufragio.

Esta obligación está, además, expresamente prevista en la Constitución. En primer lugar, y de forma amplia y general, encuentra su plasmación en el artículo 9.2, el cual consagra el principio participativo como uno de los fines fundamentales que deben perseguir los poderes públicos al disponer que éstos "están obligados a facilitar la participación de todos los ciudadanos en la vida política, económica, cultural y social"; $y$ en segundo lugar, con un alcance subjetivo muy limitado, en el artículo 68.5, dedicado a las elecciones al Congreso de los Diputados, cuando se señala que "la ley reconocerá y el Estado facilitará el ejercicio del derecho de sufragio a los españoles que se encuentren fuera del territorio de España».

Los tribunales se han referido en muchas resoluciones a este deber promocional del sufragio por parte de los poderes públicos -e incluso de los sujetos privados-, pero de todas ellas merece la pena destacar la Sentencia del Tribunal Supremo de 4 de junio de 1986, en cuyo fundamento jurídico tercero se puede leer una frase muy significativa:

"Rompiendo con el antagónico binomio derecho-deber, se considera el derecho fundamental consagrado en el artículo $23 \mathrm{CE}$, como un derecho generador de deberes sociales que imponen la participación nece-

22 Sobre el compromiso de los poderes públicos con la participación política de los ciudadanos vid. Manuel Ramírez, La participación política, Tecnos, Madrid, págs. 39-48. 
saria para expresar la conciencia social y la voluntad colectiva, puesto que la soberanía radica en el pueblo y a esa formación del sentir popular han de contribuir el titular del voto con su aportación básica y los restantes elementos de su entorno social que pueden condicionar la posibilidad de aquél y a lo que cabe añadir que los dos factores indicados son indispensables para hacer explícita la voluntad política ciudadana, en la que radica la esencia de la democracia y del sistema parlamentario» 23 .

c) Por último, para concluir el razonamiento de la fundamentación constitucional del voto por correo, hay que poner de manifiesto que esta modalidad de votación es perfectamente congruente con el deber constitucional de los poderes públicos de conseguir que el derecho de sufragio no se vea impedido o límitado en la realidad. Dicho de otra forma, existe una relación lógica, de coherencia interna, entre la obligación constitucional de facilitar el ejercicio del derecho de voto y la articulación legal del voto por correo.

Esta adecuación lógica entre el medio y el fin perseguido es perfectamente advertible sin ninguna dificultad analítica. El voto por correo hace posible -o al menos facilita- la participación en el proceso electoral de todos aquellos ciudadanos que tienen algún tipo de impedimento o dificultad más o menos grave para acercarse a su colegio electoral el día de la votación y emitir allí su voto. Es el caso de las personas que se encuentran fuera de su localidad, de quienes ejercen funciones públicas, laborales o asistenciales que no pueden abandonar sin menoscabo de las mismas, o de los que por deficiencias físicas no pueden acudir a votar; para todos ellos la previsión del voto por correo cumple una muy útil función, pues es sumamente improbable que pudieran votar del modo ordinario.

$Y$ asi ha sido admitido siempre de forma incontrovertida por todos los autores que se han ocupado de esta cuestión. Entre otros, por ejemplo, el letrado de las Cortes y profesor de Derecho Constitucional Enrique Arnaldo Alcubilla, quien ha manifestado al respecto:

«El voto por correo es una modalidad de votación que excepciona la personación del elector en la Mesa el día de las elecciones, cuyo recono-

23 Sentencia de la Sala Contencioso-Administrativa del Tribunal Supremo (Sala Tercera), que desestima un recurso de varias entidades mercantiles que exigían la responsabilidad patrimonial del Estado por las horas de trabajo perdidas como consecuencia del ejercicio de los permisos laborales para votar. Vid. también las Sentencias del Tribunal Supremo de 7 de julio de 1981, 10 de abril de 1982, 14 de mayo de 1982 y 20 de diciembre de 1990, todas del orden contencioso-administrativo, así como las Sentencias del Tribunal Constitucional 208/1989, de 14 de diciembre, y 189/1993, de 14 de junio. 
cimiento.... se funda en la ampliación y facilitación de la participación del electorado $y$, en consecuencia, de reducción de la abstención, favoreciendo el ejercicio del derecho de aquellos electores que por impedimentos físicos o profesionales no pueden acudir a votar personalmente el día de las elecciones" 24.

En definitiva, y a luz de las consideraciones anteriores, parece posible concluir que lo que decíamos al principio está perfectamente justificado: que el voto por correo tiene un sólido fundamento constitucional. En palabras de Pablo Santolaya Machetti:

"La previsión del voto por correo tiene una finalidad perfectamente acorde con los fines constitucionales; facilitar, en la medida de lo posible, remover, en los términos del artículo 9.2 de la Constitución, "los obstáculos que impidan o dificulten" el ejercicio de un derecho fundamental que constituye el momento máximo de expresión de la soberanía popular, del que depende la configuración de las instancias representativas $y$, en último extremo, el entramado de derechos y libertades del Estado democráticon 25.

\section{B) Carácter contingente}

Una vez que ha quedado acreditado el profundo engarce constitucional que tiene la previsión del voto por correo en nuestro ordenamiento jurídico, es necesario advertir inmediatamente, para evitar cualquier posible confusión sobre el alcance y configuración de esta figura, que no nos encontramos ante una medida cuya existencia sea constitucionalmente obligada. El legislador electoral español ha establecido esta modalidad de votación -contando para ello con el respaldo de la norma suprema-, pero no estaba obligado a hacerlo ${ }^{26}$.

24 Vid. Enrique ARNALDO ALCUBILLA, "Consideraciones sobre la reforma de la Ley Electoral en materia de voto por correo", en Fernando SAINZ MORENO (coordinador), IV Jornadas de Derecho Parlamentario. Reflexiones sobre el régimen electoral. Enero 1993, Congreso de los Diputados, Madrid, 1997, pág. 711 (Este artículo está también recogido con el título de "Nota sobre la segunda revisión de la Ley Electoral: el voto por correo", en El Consultor de los Ayuntamientos, núm. 23 extraordinario, diciembre de 1992). Vid. también Pablo SantolaYa MACHETTI, Manual de..., op. cit., pág. 147; Jorge de EsTEBAN, "Los conceptos generales», en VV.AA., El proceso electoral, Labor, Barcelona, 1977, pág. 68; y Richard RoSE, "En torno a las opciones en los sistemas electorales: alternativas políticas y técnicas», Revista de Estudios Políticos, núm. 34, 1983, págs. 78-79.

25 Vid. Pablo Santolaya Machetti, Manual de..., op. cit., pág. 147.

26 María Vicenta García Soriano (Elementos..., op. cit., pág. 112) se expresa en términos distintos: «El reconocimiento del sufragio universal exige el reconoci- 
La explicación de ello es bastante sencilla y se encuentra en el propio texto constitucional, que se ha limitado a imponer a los poderes públicos la obligación de facilitar el ejercicio del derecho de voto por parte de todos los ciudadanos. La Constitución exige que los poderes públicos favorezcan la expresión del sufragio, con el fin de conseguir la más amplia legitimación del poder, pero no les ha indicado la forma de hacerlo, es decir, no ha concretado en qué ha de traducirse esa acción pública de promoción del voto.

Los poderes públicos tienen, por tanto, como no podía ser de otra manera, un amplio margen de libertad para establecer las medidas de facilitación del sufragio que consideren más adecuadas, sin estar obligados a inclinarse necesariamente por unas u otras en concreto. Lo único que tienen constitucionalmente vedado en este terreno es la inacción y el entorpecimiento de tal ejercicio, así como, naturalmente, la violación de otros principios, derechos o valores constitucionales.

El uso de esta libertad ha dado lugar, como es lógico, a la adopción de determinadas medidas y al rechazo o postergación de otras. Entre las primeras cabe citar la fijación de la fecha de celebración de las elecciones en domingo o día festivo 27 , la concurrencia de distintas elecciones en una misma fecha 28 , la concesión de permisos retribuidos para votar a aquellas personas que estén trabajando el día de las elecciones ${ }^{29}$, la cercanía de las Mesas Electorales al domicilio de los

miento de la modalidad de voto por correo que se fundamenta en la necesidad de posibilitar el voto a quienes no puedan depositarlo personalmente".

27 Así lo suelen hacer los Decretos de convocatoria de las elecciones y referendos celebrados hasta el momento en nuestro país. No obstante, hay que tener en cuenta que la determinación de la fecha de las elecciones y referendos corresponde adoptarla libremente a la autoridad que tiene la facultad para hacer la correspondiente convocatoria, salvo en un caso: las elecciones locales y autonómicas cuyos Presidentes de Consejo de Gobierno no tengan atribuida expresamente por el ordenamiento la facultad de disolución anticipada; aquí las elecciones han de celebrarse necesariamente en domingo, en concreto el cuarto domingo de mayo del año que corresponda (artículo 42 LOREG).

28 Ésta es también una práctica política usual. Por ejemplo en 1999 coincidieron las elecciones locales, europeas y autonómicas; y en 2000 las elecciones a las Cortes Generales y al Parlamento de Andalucia. Como ocurre en el caso de la celebración de las elecciones en día festivo, no existe obligación legal alguna al respecto salvo en el supuesto previsto en el artículo 42.3 LOREG.

29 El artículo 13.1 del Real Decreto 605/1999, de 16 de abril, de regulación complementaria de los procesos electorales (BOE 92/1999, de 17 de abril) dice así: "La Administración del Estado o, en su caso, las de las Comunidades Autónomas que tengan atribuidas competencias en materia laboral, previo acuerdo con los Delegados del Gobierno, respecto de los trabajadores por cuenta ajena, y las Admi- 
electores ${ }^{30}$, la realización de campañas institucionales por los poderes públicos ${ }^{31} \mathrm{y}$, por supuesto, el voto por correo ${ }^{32}$. En el segundo grupo, el de las medidas de incentivación del voto no adoptadas, puede destacarse la posibilidad de voto por procuración, la ampliación del horario de la votación, el reconocimiento del voto por Internet o la remisión por la Administración a todos los ciudadanos de las papeletas electorales de las distintas candidaturas ${ }^{33}$.

En todos estos supuestos la decisión adoptada ha estado precedida de un interesante debate político y técnico sobre su oportunidad, idoneidad y eficacia. Se han valorado las ventajas que cada una tiene en términos de incentivación del voto, los problemas organizativos, presupuestarios y normativos que presenta su establecimiento y la solidez y operatividad de las alternativas existentes $y$, en función de ello, se ha llegado a una conclusión sobre su aceptación o rechazo. Así, por ejemplo, en el caso concreto del voto por correo, que es el único que en este trabajo nos interesa destacar, el legislador ha decidido establecerlo en determinados casos tras constatar las enormes dificultades que tienen determinadas personas para acercarse a las urnas el día de la votación y

nistraciones públicas, respecto a su personal, adoptarán las medidas precisas para que los electores que presten sus servicios el día de las elecciones puedan disponer en su horario laboral de hasta cuatro horas libres para el ejercicio del derecho del voto, que serán retribuidas. Cuando el trabajo se preste en jornada reducida, se efectuará la correspondiente reducción proporcional del permiso".

30 Vid. Ios artículos 23 y 24 de la LOREG. Allí se establece que las Mesas Electorales tienen entre quinientos $y$ dos mil electores, pero que en caso de población diseminada puede bajarse hasta doscientos.

31 El artículo 50.1 de la LOREG, tras la reforma efectuada por la Ley Orgánica 13/1994, de 30 de marzo, es el que se ocupa de las campañas institucionales: "Los poderes públicos que en virtud de su competencia legal hayan convocado un proceso electoral pueden realizar durante el período electoral una campaña de carácter institucional destinada a informar a los ciudadanos sobre la fecha de la votación, el procedimiento para votar y los requisitos y trámite del voto por correo, sin influir, en ningún caso, en la orientación del voto de los electores. Esta publicidad institucional se realizará en espacios gratuitos de los medios de comunicación social de titularidad pública del ámbito territorial correspondiente al proceso electoral de que se trate, suficientes para alcanzar los objetivos de esta campañan.

32 Vid. los artículos 72 a 75 y 190 de la LOREG.

33 Todas estas medidas y algunas otras han sido propuestas por diferentes personas y colectivos, habiendo sido defendidas incluso en sede parlamentaria. Así, por ejemplo, vid. las enmiendas 404 y 407 del diputado Santiago Carrillo Solares presentadas durante la tramitación de la LOREG y que pretendían sustituir el voto por correo por el voto por delegación (CORTES GENERALES, Ley Orgánica del Régimen Electoral General. Trabajos parlamentarios, dos volúmenes, edición preparada por Ramón Entrena Cuesta, Publicaciones del Congreso de los Diputados, Madrid, 1986, volumen I, págs. 404-405). 
evaluar, entre otras consideraciones, la capacidad del servicio de correos para la gestión del voto de miles de personas, la mayor o menor posibilidad de fraude que presenta esta modalidad de votación, la consistencia que tiene la alternativa constituida por el voto por medio de procurador o representante y el problema de la ruptura del principio de unidad del acto electoral, es decir, de que se excepcione para ciertos electores el sagrado y centenario rito de votar el mismo día, en las mismas condiciones y bajo el control directo del propio electorado.

En definitiva, lo que importa destacar en este momento es que el establecimiento del voto por correo constituye una pura decisión política, que corresponde adoptar libremente al legislador, y que como decisión política que es puede ser revisada en cualquier momento. Es así perfectamente posible que el voto por correo sea eliminado y deje de ser una alternativa de votación en nuestro país, tal y como ocurrió en Francia en 1975: la Ley 75-1329, de 31 de diciembre de 1975, suprimió el voto por correo para todas las elecciones políticas ante los numerosos casos de fraude que se habían detectado, dejando subsistente, aun con muchas limitaciones, la posibilidad de votar por medio de procurador 34 .

Esta observación luce todavía con mayor claridad si se tiene en cuenta que el voto por correo es una medida que no está presente en todos los países de nuestro entorno jurídico-político. La mayoría de los ordenamientos extranjeros la contemplan, con mayor o menor extensión, pero otros no (por ejemplo, Francia, Italia) ${ }^{35}$ o lo hacen sólo para

34 Hasta 1975 el Código Electoral francés contemplaba dos procedimientos de votación especiales para las personas que no pudieran comparecer en el colegio electoral el día de la votación: el voto por correo y el voto por procuración. El primero, que tenía un campo de aplicación más amplio, fue utilizado en numerosas ocasiones de forma fraudulenta, dando lugar a numerosas reclamaciones judiciales. Las constantes sombras de duda que su utilización deshonesta arrojaba sobre la limpieza de las distintas elecciones terminó por levantar un clamor popular y doctrinal contra su existencia, que fue finalmente escuchado por la mayoría parlamentaria. El voto por procuración se convirtió, entonces, en el único procedimiento especial de votación utilizable, ampliando el legislador su campo de aplicación. Vid. Jean-Claude MASCLET, Droit électoral, Presses Universitaires de France, París, 1989, págs. 282-283; André y Francine DeMiCHEL, Droit électoral, Dalloz, París, 1973; págs. 188-203 y 340-344; y Jean-Pierre Cot y Pierre GABORIT, Citoyens et candidats. La practique des élections, Robert Laffont, París, 1977, págs. 141-146.

35 Vid., por ejemplo, el artículo 55.1 de la Ley electoral de la Cámara de Diputados italiana que dice que "los electores no podrán hacerse representar ni enviar el voto por escrito" (Decreto del Presidente de la República de 30 de marzo de 1957, núm. 361, por el que se aprueba el texto único de las leyes sobre elecciones a la Cámara de los Diputados). El tema es, sin embargo, sumamente polémico 
determinada modalidad de elecciones, no para todas (por ejemplo, Bélgica) ${ }^{36}$.

\section{C) Principios informadores}

Una última precisión de carácter general y teórico resulta necesario realizar antes de adentrarnos en el estudio crítico del voto por correo en nuestro ordenamiento jurídico; y es que adoptada la decisión inicial de introducir esta modalidad de votación en España, el legislador debe ser consciente de que está obligado a seguir en su ordenación una serie de principios informadores ${ }^{37}$.

Las Cortes Generales tienen un amplio margen de libertad para regular como les parezca oportuno esta forma de expresión del sufragio, pero dicho margen no llega a ser tan amplio que no tenga límites. La libertad de acción legislativa en este terreno no es, por tanto, absoluta, sino que está sujeta a ciertas exigencias. En concreto, deben respetarse determinadas condiciones básicas del sufragio, algunas de las cuales están expresamente constitucionalizadas.

¿Y cuáles son esos principios o condiciones básicas que deben informar la regulación del voto por correo? Estos principios son muy fáciles de identificar y desarrollar. No obstante, nos vamos a limitar simplemente a enunciarlos, porque no es éste, por razones obvias, el lugar oportuno para proceder a su estudio:

1. Principio de personalidad del voto. El sufragio ha de ser emitido necesariamente por su titular y no por ninguna otra persona en su representación o interpretando su voluntad. EI derecho de sufragio, como dijo en 1980 la Junta Electoral Central es "personalísimo e intransferible» 38.

desde hace años. Sobre este debate, aunque centrado en el caso concreto de los emigrantes, vid. Enrique ARNALDO AlCUBILLA, El derecho de..., op. cit., págs. 127-141.

36 En Bélgica el voto por correo fue suprimido por ley de 5 de julio de 1976. No obstante, desde 1984 se admite para los ausentes en el extranjero en el caso de las elecciones al Parlamento europeo.

37 Así lo apunta también José L. Ruiz-Navarro Pinar, "Artículo 73», en Luis M. a Cazorla Prieto (director), Comentarios a la Ley Orgánica del Régimen Electoral General, Cívitas, Madrid, 1986, págs. 691-692. Los legisladores también son conscientes de ello. Así vid. Diario de Sesiones del Congreso de los Diputados. IV Legislatura. Pleno, núm. 170, de 3 de marzo de 1992, págs. 8335 y 8336.

38 Vid. el Acuerdo de la Junta Electoral Central de 21 de noviembre de 1980, reiterado el 15 de septiembre de 1982 (Apud Enrique Arnaldo Alcubilla y 
2. Principio de autenticidad del voto. El sentido del voto escrutado por el órgano encargado de su cómputo ha de tener correspondencia exacta con el efectivamente emitido por el elector. No puede haber interferencias que defrauden su voluntad.

3. Principio de libertad de voto. La expresión del sufragio ha de responder a la efectiva voluntad del elector. Los ciudadanos no pueden ser obligados o coaccionados bajo ningún pretexto a la hora de ejercer su derecho de sufragio ${ }^{39}$.

4. Principio de secreto del voto. El voto es un acto individual, solitario e íntimo del elector. Todos están obligados a respetar la opacidad sobre la opción electoral escogida por el elector 40.

5. Principio de igualdad del voto. La democracia está asentada en la fórmula "un hombre un voto". No cabe admitir las situaciones que conducen a la doble emisión del voto por una misma persona 41.

6. Principio de facilitación del sufragio. El procedimiento de emisión del voto no puede desanimar a nadie de llevar a la práctica su deseo de ejercer su derecho. Nadie debe renunciar a votar ni por razones económicas, ni por el esfuerzo de tiempo a emplear, ni por la dificultad que ofrezca la comprensión de los trámites ${ }^{42}$.

7. Principio de efectividad del voto. El sufragio ha de ser expresado en tiempo y forma tal que no se liegue a perder o se deje de computar. Ha de haber una razonable confianza en que el voto emitido va a ser objeto de cómputo efectivo por la Mesa escrutadora, de tal modo que los electores alcancen una participación efectiva en las elecciones y no meramente nominal o imperfecta.

Todos estos principios expuestos sucintamente son los nortes, los criterios inspiradores de la regulación del voto por correo en nuestro ordenamiento, e incluso de cualquier otro ordenamiento que se precie de ser democrático, pues son deducibles de la propia esencia del

Manuel Delgado-lribarren Garcia-Campero, Código electoral, 3. a edición, Abella, Madrid, 1999, vol. I, pág. 404). 5 de la LOREG.

39 Vid. los artículos $23.1,68.1$ y 69.2 de la Constitución, así como el artículo

40 Ibídem.

41 Vid. los artículos 68.1 y 69.2 de la Constitución, además del artículo 1.1 que configura la igualdad como uno de los valores superiores del ordenamiento jurídico.

42 Vid. los artículos 9.2, 23.1 y 68.5 de la Constitución. 
derecho de sufragio. La propia lógica del Estado democrático exige que el voto por correo se ajuste a los principios de personalidad, autenticidad, libertad, secreto, igualdad, facilidad de expresión y efectividad del voto, aplicables también, como es evidente, a la expresión del voto por personación del elector en la Mesa Electoral que le corresponda; se trata, en definitiva, si se piensa bien, de exigir que el voto por correo se emita en las condiciones más similares posibles al voto ordinario o emitido directamente en la Mesa Electoral.

Esta exigencia no es, sin embargo, nada fácil de satisfacer. El problema radica en que estos principios son muy difíciles de conciliar entre sí, pues la consecución de unos implica, de forma inevitable, el descuido o perjuicio de otros. La tensión se produce, en concreto, entre los principios de personalidad, autenticidad, libertad, secreto e igualdad del voto, por un lado, y los de facilidad de expresión y efectividad del voto, por otro. Así, por ejemplo, es evidente que si se establece un procedimiento de votación por correo muy riguroso para impedir cualquier clase de fraude, existen grandes posibilidades de que muchos electores, ante la complejidad de los trámites a seguir, decidan no hacer uso de esta modalidad de votación o de que los votos emitidos no lleguen a tiempo de ser contabilizados; por el contrario, si se establece un procedimiento ágil, con pocas exigencias y controles, se favorece la expresión del sufragio, pero lo que resulta lesionado entonces es la pureza de las elecciones.

El problema es grave y difícil de solucionar, tal y como ha puesto de relieve la doctrina. Así lo hace, por ejemplo, Pablo Santolaya Machetti:

“Este conjunto de exigencias puede, sin embargo, resultar difícil de conciliar. De nada serviría un mecanismo plenamente garantístico del carácter libre y secreto de los votos no emitidos en las Mesas si fuera de tan extrema complejidad que no pudiera ser utilizado en tiempo $y$ forma. Por otra parte, no resultaría aceptable un procedimiento sencillo y rapidísimo que permitiese el falseamiento o manipulación de los sufragios. La regulación concreta debe valorar ambos riesgos y conseguir un siempre difícil equilibrio entre ellos» 43 .

Y en la solución de este problema radica precisamente, como ya habrá adivinado el lector que nos haya seguido hasta aquí, una parte

43 Vid. Pablo Santolaya Machetti, Manual de..., op. cit., pág. 148. Vid. también Enrique ARNALDo AlCUBILLA, "Consideraciones sobre...", op. cit., pág. 712; José

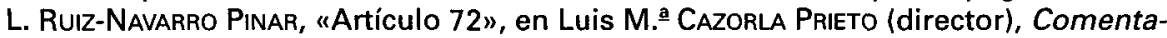
rios..., op. cit., pág. 688; y Jean-Claude MASCLET, Droit électoral, op. cit., pág. 282. 
importante de la clave del trabajo que estamos abordando. Si el legislador es capaz de integrar de forma satisfactoria todo este conjunto de principios, su labor merecerá un juicio global favorable, con independencia de que pueda ser mejorable en aspectos de detalle o de que pueda darse mayor campo al voto por personación en la Mesas Electorales, pero si no lo consigue, la valoración ha de ser forzosamente negativa y la consecuencia no puede ser otra que la de proceder a la inmediata reforma de los puntos deficientes por violación del contenido esencial del derecho de sufragio. Esto es algo, sin embargo, de lo que nos vamos a ocupar en los dos apartados que siguen.

\section{LA REGULACIÓN DEL VOTO POR CORREO EN ESPAÑA}

\section{A) Supuestos en que procede}

La doctrina constitucional de los diferentes países democráticos viene discutiendo, desde casi la misma aparición del voto por correo, sobre la mayor o menor extensión con que las leyes electorales deben reconocer a los ciudadanos la posibilidad de utilizar esta modalidad de votación ${ }^{44}$. Las posiciones mantenidas al respecto son, como es natural, muy variadas, pero todas ellas pueden sintetizarse básicamente en las tres siguientes:

- La primera y más extendida propugna que el voto por correo sea una modalidad de votación de carácter excepcional, limitada a aquellas categorías de ciudadanos para los que realmente no exista la alternativa de votación en las Mesas Electorales. A estos electores o se les deja votar por correo o no podrán ejercer su derecho de sufragio.

- Una segunda posición, más minoritaria, sostiene que el voto por correo debe ser una opción libre para los ciudadanos, es decir, abierta a cualquier elector que, por la razón que sea, desee utilizar esta vía de expresión del sufragio. Los ciudadanos pueden votar en la Mesa Electoral el día de la votación o pueden también, si así lo desean, votar por correo con cierta antelación y cumpliendo lógicamente el procedimiento legalmente establecido, que en la generalidad de los casos será más gravoso que el primero.

44 Vid. W. J. M. MACKeNCIE, Elecciones libres, Tecnos, Madrid, 1962, pág. 144; Pablo Santolaya Machetti, Manual de..., op. cit., pág. 148; y Eduardo Espín TeMPLADO, "Desarrollo y...», op. cit., págs. 144-145. 
- Por último, tenemos la postura casi testimonial de quienes defienden la preeminencia del voto por correspondencia, es decir, de los que reclaman que esta modalidad de votación se convierta en la vía ordinaria o incluso única de emisión del voto. Los ciudadanos tendrían, por tanto, que votar necesariamente por correo, salvo, en su caso, en aquellos supuestos excepcionales en que se considere justificado utilizar otra vía alternativa de votación (por ejemplo, el voto por delegación para los electores residentes en un país extranjero cuyo servicio de correos sea muy deficiente).

Estas tres posiciones han encontrado aplicación, con mayor o menor grado de pureza o variación, en el Derecho comparado. Las más extendidas son, indudablemente, las dos primeras, aunque la tercera tesis también ha encontrado acogida en algunos países: por ejemplo, Estados Unidos, en donde alguno de sus Estados integrantes ha establecido el voto por correo como modalidad única de votación para algunas elecciones 45; o el Reino Unido, que lo utilizó desde 1918 a 1950 en las antiguas circunscripciones electorales universitarias ${ }^{46}$.

¿Y qué posición se ha seguido en nuestro país? Aunque parezca una forma inocente y refinada de eludir la cuestión, hay que reconocer con toda franqueza que es sumamente difícil averiguarlo a primera vista. Y la cuestión no está nada clara porque la LOREG contiene sobre el papel elementos propios de las tres posiciones citadas. Veámoslo:

- La posición que contempla el voto por correo como una forma de votación excepcional tiene acogida en el artículo 72.1 de la LOREG, que se ocupa de determinar cuándo los ciudadanos inscritos en el censo de electores residentes en España tienen la posibilidad de votar por correo. Los electores residentes en el país tienen como modalidad ordinaria de votación el voto por personación en la Mesa Electoral que les corresponda, pero en determinados casos previstos en la ley pueden votar por correo; en concreto pueden hacerlo cuando "prevean que en la fecha de la votación no se hallarán en la localidad donde les corresponda ejercer su derecho de voto o que no puedan personarse".

45 Este es el caso del Estado de Oregón, que en 1997 decidió en referéndum que el voto por correo fuera la modalidad única de votación en las elecciones primarias y presidenciales.

46 Vid. W. J. M. MACKENCIE, Elecciones..., op. cit., pág. 144. 
- La segunda posición a que antes aludimos, esto es, la que informada por el principio participativo configura el voto por correo como una opción tan ordinaria como cualquier otra que se establezca, encuentra aplicación en el artículo 75 de la LOREG, dedicado al voto de los electores residentes ausentes en las elecciones generales, autonómicas y europeas. Allí se determina que este tipo de electores pueden utilizar indistintamente la vía del voto por correo o la de la entrega directa de los sobres de votación en las Embajadas y Consulados españoles en el extranjero para su remisión por valija diplomática al Ministerio de Asuntos Exteriores y de allí a las Juntas Electorales encargadas del escrutinio 47.

- Finalmente, la posición más favorable al voto por correo opera en el reducido campo del voto de los electores residentes-ausentes en las elecciones locales y está regulado en el articulo 190 de la Ley electoral. Para estos electores, y tratándose de esta concreta modalidad de elecciones (a ayuntamientos, cabildos insulares, etc.), el voto por correo no es una opción más o menos ordinaria u excepcional, sino la única forma de votación disponible, pues el legislador no ha previsto la posibilidad de que puedan entregar su voto en los Consulados y Embajadas de España, como sí sucede, en cambio, como hemos visto, en los demás tipos de elecciones.

Este es, en apretado resumen, el marco de aplicación del voto por correo que resulta de una primera aproximación al articulado de la LOREG. No obstante, si profundizamos un poco más en el análisis normativo y fáctico el panorama varía un poco. Es posible descubrir, entonces, que nuestro Derecho no ha recogido realmente en el artículo 72.1 de la LOREG la tesis del voto por correo como una modalidad excepcional de emisión del voto, sino la que articula esta forma de votación como opción libre del elector, y que, además, esta segunda posición es ampliamente predominante respecto de la tercera en liza.

47 La vía de la entrega directa de los sobres de votación en las Embajadas y Consulados de España en el extranjero fue introducida por la Ley Orgánica 3/1995, de 23 de marzo, de modificación de la LOREG. Hasta entonces en las elecciones generales, autonómica y europeas solo se podía votar por correo. Sobre esta reforma vid. Enrique ARNALDO ALCUBILLA, El derecho de..., op. cit., págs. 357 y ss. Lo que no cabe en ningún caso por parte de los electores residentes ausentes es la entrega personal del sobre de votación en la Mesa Electoral en la que estén inscrito. Vid. los Acuerdos de la Junta Electoral Central de 24 y 27 de febrero de 1986 y de 28 de mayo de 1995 (Apud Enrique Arnaldo Alcubilla y Manuel Delgado-Iribarren GarCIA-CAMPERo, Código..., op. cit., págs. 404 y 406). 
Esto es así por varias razones. En primer lugar, y respecto del desvanecimiento de la tesis restrictiva frente a la híbrida $u$ optativa, hay que tener en cuenta que al elector ordinario, aquel que tiene su residencia efectiva en España, no se le exige acreditación alguna de las razones que le llevan a utilizar esta vía de votación 48 . Estos electores no tienen que justificar ante nadie, ni documentalmente ni de ninguna otra forma, qué motivo tienen para prever que no van a estar en su localidad el día de la votación o que aun estando en la misma no van a poder personarse en la Mesa Electoral para emitir su voto; basta con que ellos, en la intimidad de su conciencia, consideren que no van a poder hacerlo, sin que se hayan establecido ulteriores exigencias o comprobaciones. Y si esto es así la consecuencia es bastante clara: el voto por correo es, en la práctica, un procedimiento ordinario de votación para los electores residentes, alternativo al voto por personación en las Mesas Electorales; cualquier elector que no desee acudir a su colegio electoral el día de la votación puede emitir su voto por correo anticipadamente, aun cuando no tenga ninguna razón objetiva que se lo impida ${ }^{49}$.

En segundo lugar, y para justificar la preponderancia que el sistema optativo de voto por correo alcanza en nuestro Derecho, hay que tener presente un elemento fáctico de gran interés: que los electores residentes-ausentes que vayan a votar en las elecciones locales, que son los únicos ciudadanos españoles que no pueden optar entre distintas formas de votación al estar obligados a utilizar necesariamente el voto por correo, tienen una importancia cuantitativa bastante modesta; suponen alrededor del $2 \%$ del total de ciudadanos con derecho de voto en nuestro país y de ellos apenas un tercio suele ejercer su sufragio 50 .

No quisiéramos concluir este apartado sin hacer una referencia, aunque sea somera, a la valoración que merece la delimitación del

48 El Grupo Parlamentario Socialista del Congreso de los Diputados propuso, durante la tramitación parlamentaria de la reforma de la LOREG de 1993, la obligación de "acreditar fehacientemente tales circunstancias", pero la Ponencia no lo consideró oportuno. Vid. Boletín Oficial de las Cortes Generales. Congreso de los Diputados, Serie B, núm. 107-5, de 25 de abril de 1992, pág. 11; y núm. 107-7, de 18 de mayo de 1992, págs. 17-18.

49 Vid. Enrique ARnaldo AlcubiLla, El derecho de..., op. cit., págs. 353-354; José L. Ruiz-Navarro PInaR, "Artículo 72», op. cit., págs. 686-687; Pablo Santolaya MaChetTI, Manual de..., op. cit., pág. 150 y "La crisis del...", op. cit., pág. 459; y Andrés Torre Serrano, "El voto por correspondencia», Actualidad Administrativa, núm. 40, 1989 (semana del 30 de octubre al 5 de noviembre), pág. 2506.

50 Por ejemplo, en las elecciones locales de 1999 el porcentaje de electores residentes ausentes que ejerció su sufragio no alcanzó ni el $0,5 \%$ sobre el censo electoral total. 
campo de aplicación del voto por correo en nuestro Derecho. Aunque ésta sea una cuestión más propia de las consideraciones finales que nos proponemos llevar a cabo en el apartado último del trabajo, no nos resistimos a realizar ahora alguna indicación al respecto.

Nuestra opinión, dicha en pocas palabras, es poco favorable a la delimitación efectuada por la ley. Con independencia de cómo esté configurado concretamente el procedimiento de votación por correo, cuestión que abordaremos en el apartado siguiente, son tres los puntos críticos que quisiéramos resaltar en este momento. Aunque luego puedan ser objeto de algunas matizaciones y comentarios adicionales, los expondremos ahora de forma franca y abierta:

1. La extraordinaria amplitud que el voto por correo tiene en España, lo cual no sólo extiende e intensifica el menoscabo que el principio de unidad del acto electoral sufre necesariamente con el mismo reconocimiento de esta modalidad de votación, sino que hace también, en principio, extraordinariamente complicada y difícil la sujeción del voto por correo a los principios que, como vimos en su momento, lo deben informar. Es poco discutible que para la correcta gestión, desarrollo y control del voto por correo no puede ser indiferente el aspecto cuantitativo; no es lo mismo, por ejemplo, garantizar la efectividad del voto por correo de cincuenta mil potenciales electores que de millón y medio ${ }^{51}$.

2. La discordancia en la forma de votación de los electores residentes ausentes según el tipo de elección: en las elecciones generales, autonómicas y europeas estos electores pueden votar por correo o depositar el sobre de votación en las Embajadas y Consulados españoles, pero en las elecciones locales tan sólo pueden utilizar la primera via de expresión del sufragio. Esta divergencia, difícil de justificar, no puede hacer más que confundir al elector e impedir la deseable identificación de la ciudadanía con un sistema de votación fácilmente reconocible. Piénsese, incluso, que cuando las elecciones locales coincidan con otras, como suele pasar, el elector tendrá que acudir necesariamente al servicio de correos de su país de residencia para votar en las primeras (las locales), pero que podrá acercarse a la embajada española correspondiente y entregar su voto para las demás (generales, autonómicas y europeas).

51 Vid. Pablo Santolaya Machetti, Manual de..., op. cit., págs. 149-150. 
3. La intervención de los servicios de correos de países extranjeros en el envío de las papeletas de votación a los electores residentes-ausentes y en la tramitación de sus votos, dándose la circunstancia de que tales servicios dejan, en gran parte de los casos, mucho que desear; dicho más claro, funcionan muy deficientemente, poniendo en serio peligro la utilidad $y$ pureza de esta forma de votación. Quizá radique aquí la causa de que en las elecciones generales de 1996, por poner un ejemplo cualquiera, se hicieran 1.158 envíos de papeletas electorales a los españoles residentes en Cuba y no se recibiera ni un sólo voto de ellos 52 .

\section{B) Procedimiento}

Una vez que sabemos quién puede votar por correo, debemos plantearnos la cuestión del cómo hay que hacerlo. Esto supone, dicho con otras palabras, abordar el examen del concreto procedimiento establecido en nuestro Derecho para utilizar esta modalidad de votación.

Y lo primero que hay que decir a este respecto es que en nuestro país no existe un único procedimiento sino varios. Los poderes públicos, conscientes de las diferentes situaciones en que pueden encontrarse los ciudadanos a los que les resulta difícil o imposible acercarse a las Mesas Electorales para expresar su sufragio, han establecido, junto a un procedimiento general de votación por correo abierto a todos los ciudadanos, una serie de procedimientos especiales para determinados colectivos: enfermos e imposibilitados, marineros, etc.

\section{a) Procedimiento ordinario}

El procedimiento ordinario de votación por correo está regulado en los artículos 72,73 y 88.2 de la LOREG. El desarrollo del mismo puede resumirse en las siguientes fases, ordenadas cronológicamente.

1. La primera actuación del procedimiento corre a cargo del elector, el cual debe solicitar un certificado de inscripción en el censo a la correspondiente Delegación Provincial de la Oficinal del Censo Elec-

52 Apud Pablo Santolaya Machetti, Manual de..., op. cit., pág. 156. 
toral (en adelante OCE). Esta solicitud debe formularse personalmente ante cualquier Oficina del Servicio de Correos 53 a partir de la fecha de la convocatoria de las elecciones y hasta el décimo día anterior al de la votación ${ }^{54}$. Para asegurar el cumplimiento de la formulación personal de la solicitud, la Ley impone al funcionario de Correos encargado de recibirla la obligación de exigir al interesado la exhibición de su Documento Nacional de Identidad y de comprobar la coincidencia de la firma. Asimismo le indica que no debe admitir fotocopia de dicho documento ${ }^{55}$.

2. Una vez que el elector ha realizado su solicitud, el Servicio de Correos debe remitirla en el plazo de tres días a la correspondiente Delegación Provincial de la OCE. Entendemos que se trata de un plazo máximo, por lo que el Servicio de Correos, en la medida en que sea posible, deberá tramitar las solicitudes inmediatamente, a fin de dar la

53 El Gobierno ha sido consciente de que las mismas dificultades que puede tener una persona para votar en su Mesa Electoral el día de las elecciones, puede tenerla para hacer la solicitud del certificado de inscripción en el censo durante el periodo electoral y, en consecuencia, ha previsto la existencia de permisos laborales para acercarse a Correos y hacer su solicitud. Lo hace en el artículo 13.2 del Real Decreto 605/1999, de 16 de abril, de regulación complementaria de los procesos electorales.

54 Hasta la reforma de 1992 el plazo era más amplio, pues llegaba en su parte final hasta el quinto día anterior al de las elecciones, lo que dejaba muy poco margen de tiempo para la realización de los demás trámites, poniendo en serio peligro la efectividad del voto de los ciudadanos que hacían uso de esta vía. Vid. Andrés ToRre SERRANo, «El voto...», op. cit., págs. 2506-2507.

55 La Junta Electoral Central, por su parte, ha admitido, haciendo una aplicación analógica de lo dispuesto en el artículo 85 de la LOREG para la votación por personación en la Mesa Electoral, que la identidad del elector pueda acreditarse no solo con el Documento Nacional de Identidad, sino también con el pasaporte o carné de conducir siempre que tales documentos contengan la fotografía y la firma del elector (Acuerdos de 18 de junio de 1986, 8 de mayo de 1989, 28 de abril de 1995 y 24 de mayo de 1995. Apud Enrique Arnaldo AlCubilla y Manuel Delgado-Iribarren Garcia-Campero, Código..., op. cit., pág. 387). Igualmente ha aceptado la validez acreditativa de tales documentos cuando se encuentran caducados (Acuerdos de 8 de mayo de 1989, 5 y 12 de mayo de 1993 y 24 de mayo de 1995. Apud Enrique Arnaldo Alcubilla y Manuel Delgado-Iribarren Garcia-CamPERo, Código..., op. cit., pág. 387). El Senado aprobó en 1992, a partir de una enmienda del Grupo Parlamentario de los Senadores Nacionalistas Vascos, que el contenido de esta doctrina de la Junta Electoral Central se trasladara al texto del artículo 72, pero en el Congreso de los Diputados no hubo mayoria suficiente para aprobar las distintas enmiendas introducidas por el Senado (votaron a favor de ellas 169 diputados cuando hacían falta 176 (Vid. el texto aprobado en el Senado en el Boletín Oficial de las Cortes Generales. Senado, Serie III B, núm. 23 f, de 6 de octubre de 1992, pág. 20). 
mayor celeridad al procedimiento y con ello garantizar el principio de efectividad del sufragio ${ }^{56}$.

3. Recibida la solicitud por la pertinente Delegación Provincial de la OCE, ésta debe llevar a cabo una serie de actuaciones: comprobar que el solicitante está efectivamente inscrito en el censo electoral; realizar en éste la anotación de que el elector va a votar por correo a fin -dice la ley expresamente- de que el día de las elecciones no realice el voto personalmente; extender el certificado de inscripción en el censo que le ha sido solicitado; $y$, finalmente, enviárselo al elector a partir del trigésimo cuarto día posterior a la convocatoria y antes del sexto día anterior al de la votación junto con otros documentos: las papeletas de las candidaturas electorales que se presentan en la circunscripción, el sobre o sobres de votación en donde deben introducirse las papeletas elegidas, un sobre más grande que el anterior en el que figure la dirección de la Mesa Electoral donde le corresponde votar y una hoja explicativa sobre cómo votar 57 .

La remisión de esta documentación ha de hacerse por correo certificado al domicilio indicado por el elector o, en su caso, al que figure en el censo, exigiéndose, además, que el envío sea recibido personalmente por el interesado ${ }^{58}$. A estos efectos dice la Ley que el aviso de recibo acreditativo de la recepción de la documentación sea firmado personalmente por el interesado, previa acreditación de su identidad, y que en el caso de no encontrarse en su domicilio se le comunique que deberá personarse por sí o, caso de estar enfermo, a través de la representación regulada en el procedimiento especial para el voto de este colectivo, en la oficina de Correos correspondiente para, previa acreditación, recibir la documentación.

4. Una vez que la documentación para el voto por correo está en poder del elector tiene lugar el momento más relevante del procedi-

56 El artículo 72-d) dice así: "Los servicios de Correos remitirán en el plazo de tres días toda la documentación presentada ante los mismos a la Oficina del Censo electoral correspondiente." Hemos interpretado que este plazo se aplica a cada solicitud individual y no al conjunto de todas las presentadas, por considerar que es más conforme con la celeridad que ha de informar todo el procedimiento.

57 Si falta algún documento es necesario remitir nuevamente toda la documentación. Así lo ha declarado expresamente la Junta Electoral Central (Acuerdo de 18 de junio de 1986. Apud Enrique Arnaldo Alcubilla y Manuel Delgado-Iribarren Garcia-Campero, Código..., op. cit., pág. 392).

58 La libertad de indicación del domicilio no es, sin embargo, absoluta, pues la Junta Electoral Central ha señalado que no puede indicarse un domicilio fuera del territorio nacional, habida cuenta que el envío tiene que ser recibido personalmente por el elector (Acuerdo de 12 de mayo de 1993. Apud Enrique ARNALDo Alcubilla y Manuel Delgado-Iribarren Garcia-Campero, Código..., op. cit., pág. 392). 
miento: la emisión del voto y su correspondiente envío al órgano escrutador. Para ello el elector debe escoger o, en su caso, rellenar la papeleta de voto, introducirla en el sobre de votación, meter este sobre junto con el certificado de inscripción en el censo en el sobre dirigido a la Mesa Electoral que le corresponda y, finalmente, remitírselo a ésta por correo certificado antes del tercer día previo al de la celebración de las elecciones ${ }^{59}$. Es importante tener en cuenta que la Ley no exige que el elector tenga que acudir personalmente a certificar el sobre electoral ${ }^{60}$. Lo que, en cambio, sí dice la Ley es que este sobre no necesita franqueo, aunque esta declaración no era, a nuestro juicio, estrictamente necesaria, pues el artículo 118 de la misma establece con carácter general la gratuidad de todas las actuaciones relativas al procedimiento electoral 61 .

5. A las nueve horas del día de la votación el Servicio de Correos debe trasladar los sobres recibidos a las correspondientes Mesas Electorales. Asimismo, debe seguir dando traslado de los que reciba a lo largo del día, pero antes de las veinte horas, momento en que concluye oficialmente el horario de votación en los colegios electorales. La correspondencia electoral que se reciba con posterioridad deberá ser remitida a las Juntas Electorales de Zona, que como es lógico deberán proceder a su destrucción ${ }^{62}$.

59 En caso de que el elector envíe por error el sobre a través del correo ordinario, ha indicado la Junta Electoral Central que el Servicio de Correos debe devolvérselo al remitente y poner en su conocimiento el motivo por el que se to devuelve, permitiéndole así que pueda remitirlo de nuevo pero de forma certificada. Vid. los Acuerdos de 5 de junio de 1989 y 28 de mayo de 1995, así como los de 5 de mayo de 1993, 6 de junio de 1993 y 30 de mayo de 1994 que resuelven determinadas incidencias sobre la localización del elector (Apud Enrique ARNALDo ALCUBILLA y Manuel Delgado-Iribarren Garcia-Campero, Código..., op. cit., pág. 394).

60 Vid. los Acuerdos de la Junta Electoral Central de 21 de mayo de 1991, 24 de abril de 1995 y 10 de mayo de 1995 (Apud Enrique ARNALDo AlcubiLLA y Manuel Delgado-Iribarren Garcia-Campero, Código..., op. cit., págs. 393-394).

61 El artículo 118.1 de la LOREG dice así: "Tienen carácter gratuito, están exentos del impuesto sobre actos jurídicos documentados y se extienden en papel común: a) Las solicitudes, certificaciones y diligencias referentes a la formación, revisión e inscripción en el Censo Electoral. b) Todas las actuaciones y los documentos en que se materializan, relativos al procedimiento electoral, incluidos los de carácter notarial».

62 Así lo ha señalado la Junta Electoral Central en su Acuerdo de 2 de junio de 1995 (Apud Enrique Arnaldo Alcubilla y Manuel Delgado-Iribarren Garcia-CamPERO, Código..., op. cit., pág. 396). El Real Decreto Ley 20/1977, de 18 de marzo, sobre normas electorales establecía expresamente esta solución en su articulado, en concreto en el artículo 57.5: "Si la correspondencia electoral fuera recibida en el local de la sección con posterioridad a la terminación de la votación, no se computará ni 
6. Finalmente tiene lugar la intervención de las Mesas Electorales. Una vez que terminan de votar los electores que se han acercado a los colegios electorales en el horario oficial, el Presidente de la Mesa debe cerciorarse de que el sobre electoral está certificado y ha sido enviado en fecha hábil. A continuación debe abrirlo y comprobar que el elector ha metido en el mismo el sobre de votación y el certificado de inscripción en el censo. Si esta comprobación es positiva debe introducir el sobre en la urna, mientras los Vocales anotan el nombre del elector en la lista numerada de votantes 63 .

Una vez realizada sumariamente la descripción sistemática del procedimiento ordinario de votación por correo, parece conveniente detener un momento la marcha y ofrecer una valoración general y de conjunto sobre dicho procedimiento, de forma semejante a lo que hicimos cuando examinamos en el punto anterior los supuestos en que procede utilizar el voto por correo.

Puestos a esta tarea hay que comenzar por afirmar que el procedimiento examinado nos ha dejado un sentimiento valorativo ambivalente, pues nos parece que junto a elementos sumamente positivos y apreciables, existen también importantes deficiencias susceptibles de revisión. Vamos a ver brevemente estas consideraciones de forma separada.

En el aspecto positivo cabría destacar los siguientes aspectos de la regulación actual:

se estimará como votante al elector. El Presidente, si aún permaneciese en el local, o en su caso, la propia Oficina de Correos, la remitirá a la Junta Electoral de Zona. Esta celebrará sesión dentro de las setenta y dos horas siguientes al día de la elección, en la que se incinerarán sin abrirlos todos los sobres con papeletas electorales y que hayan sido recibidos después de la terminación de la votación". Durante la tramitación de la LOREG en el Congreso de los Diputados el Partido Popular propuso recoger en su articulado el contenido de este precepto del Real Decreto Ley (enmienda núm. 598), pero la Ponencia constituida en el seno de la Comisión Constitucional de esta Cámara no lo consideró «necesario» (Apud CORTES GENERALES, Ley Orgánica del Régimen Electoral...., op. cit., págs. 347 y 375).

63 El artículo 88 de la LOREG no es tan ordenado a la hora de expresar los trámites que ha de hacer la Mesa Electoral: «1. A las veinte horas el Presidente anunciará en voz alta que se va a concluir la votación. Si alguno de los electores que se hallan en el local o en el acceso al mismo no ha votado todavía, el Presidente admitirá que lo hagan y no permitirá que vote nadie más. 2. Acto seguido el Presidente procede a introducir en la urna los sobres que contengan las papeletas de voto remitidas por correo, verificando antes que se cumplen las circunstancias expresadas en el párrafo tercero del artículo 73 y que el elector se halla inscrito en las listas del Censo. Seguidamente, los Vocales anotarán el nombre de estos electores en la lista numerada de votantes". 
1. La necesidad de que el elector obtenga el certificado de inscripción en el censo para poder votar por correo. Este certificado es muy valioso: en primer lugar, permite a los ciudadanos cerciorarse de que pueden ejercer su sufragio y, por tanto, que la emisión de su voto no será inútil; en segundo lugar, les indica cuál es la Mesa Electoral a la que deben dirigir el sobre de votación; y, por último, les cierra la posibilidad de que puedan votar doblemente (por correo y por personación en la Mesa Electoral), pues la OCE debe anotar en el censo-cuyas copias utilizarán las Mesas Electorales- que el solicitante va a votar por correo (artículo 73.1 LOREG) 64.

2. La existencia de un único órgano legitimado (el Servicio de Correos) para recibir las solicitudes para votar por correo. Esta opción legislativa -que excepciona la regla general sobre presentación de escritos que contiene la Ley 30/1992, de 26 de noviembre, de régimen jurídico de las Administraciones Públicas y del procedimiento administrativo común 65 - parece razonable, pues la centralización de las solicitudes en un sólo organismo favorece el control sobre el correcto ejercicio del voto por correo. Además, hay que tener en cuenta que la habilitación de otros órganos -y pienso sobre todo en las Delegaciones Provinciales de la OCE- supondría distraerlos de otras importantes funciones que cumplen en el proceso electoral, sin obtenerse a cambio ningún beneficio evidente 66 .

3. La necesidad de acreditar la identidad del elector en algún momento del procedimiento. La ley lo exige en dos ocasiones: en el momento en que el elector presenta su solicitud para votar por correo;

64 El Decreto 1796/1967, de 20 de julio, por el que se dictan normas complementarias de la Ley de Representación Familiar en Cortes, que es la primera norma electoral que en nuestro país contempló el voto por correo, no preveía la obtención de este certificado, sino que el elector directamente enviaba el sobre de votación a la Mesa Electoral que le correspondía (artículo 23).

65 Vid. el artículo 38 de la Ley $30 / 1992$, de 26 de noviembre, de régimen jurídico de las Administraciones Públicas y del Procedimiento Administrativo Común.

66 El Real Decreto Ley 20/1977, de 18 de marzo, sobre normas electorales acogía la solución contraria, pues se remitía expresamente a la Ley de Procedimiento Administrativo, aunque con alguna pequeña modificación (artículo 57.1-b). El tema fue, además, objeto de controversia durante tramitación parlamentaria de la LOREG. Así, por ejemplo, el Partido Nacionalista Vasco propuso ampliar el círculo de los órganos legitimados para tramitar el voto: Juntas Electorales de Zona, Oficinas de Correos, Ayuntamientos, Gobiernos Civiles, Gobiernos Militares y Delegaciones Provinciales de la OCE (Vid. las enmiendas 215 en el Congreso y 120 en el Senado. Apud CORTES GENERALES, Ley Orgánica del Régimen..., op. cit., vol. I, págs. 204-205, y vol. II, pág. 850). 
y en el instante en que recibe de la Delegación Provincial de la OCE la documentación electoral necesaria para ejercer su sufragio 67.

4. El establecimiento de plazos preclusivos en todas las fases del procedimiento, única vía de garantizar eficazmente el principio de efectividad del voto. El detallismo de la ley es evidente, sobre todo tras la reforma electoral de 1992: el elector debe solicitar el certificado de inscripción en el censo ua partir de la fecha de convocatoria y hasta el décimo día anterior al de la votación»; el Servicio de Correos dispone de un "plazo de tres dias" para remitir esta solicitud a la Delegación Provincial de la OCE; esta Delegación debe enviarle el certificado junto con los demás documentos necesarios para votar "a partir del trigésimo cuarto día posterior a la convocatoria y antes del sexto día anterior al de la votación"; el elector tiene que depositar el voto en Correos "antes del tercer día previo al de la celebración de las elecciones"; el Servicio de Correos debe trasladar la correspondencia recibida a las Mesas Electorales "a las 9 de la mañana" del día de la votación y debe seguir "dando traslado de la que pueda recibirse en dicho día hasta las veinte horas"; por último, una vez que concluye la votación de los electores que votan directamente en la Mesa Electoral, el Presidente de la misma, según establece el artículo 88 de la LOREG, procede a introducir en la urna los sobres que contengan las papeletas de voto remitidas por correo.

5. La directa intervención de la OCE para la gestión de los certificados de inscripción en el censo. La doctrina viene cuestionando desde hace años la oportunidad de que sea la OCE, un órgano encuadrado en el Instituto Nacional de Estadística 68 , quien se encargue de este trámite, y no la Junta Electoral que corresponda (Provinciales o de Zona), como sucedía bajo la vigencia del Real Decreto Ley 20/1977, de 18 de marzo, sobre normas electorales ${ }^{69}$, pero parece que tanto el hecho de que la OCE esté bajo el control de la Junta Electoral Central como las

67 La primera exigencia de acreditación de la personalidad del elector está presente en la LOREG desde el principio, pero la segunda no: fue introducida en 1992 a iniciativa socialista (Vid. el Boletín Oficial de las Cortes Generales. Congreso de los Diputados, Serie B, núm. 107-5, de 25 de abril de 1992, pág. 11). Por otra parte, conviene saber que el Real Decreto Ley 20/1977, de 18 de marzo, sobre normas electorales adoptaba una posición radicalmente opuesta: permitía hacer la solicitud del certificado de inscripción en el censo por medio de representante y no exigía certificación alguna de la recepción por el destinatario de la documentación electoral. 29 y 30.

68 La Oficinal del Censo Electoral es regulada por la LOREG en los artículos

69 Vid. el artículo 57.1 del Real Decreto Ley 20/1977, de 18 de marzo, sobre normas electorales, que atribuía esta competencia a la Junta Electoral de Zona. 
exigencias de rapidez y eficacia del procedimiento avalan la bondad de la solución actual 70 .

6. Las exigencias de certificación y gratuidad de todos los envíos, según se desprende de la LOREG y ponen de manifiesto con más claridad aún las distintas órdenes aprobadas por el Ministerio de Transportes sobre colaboración de los Servicios de Correos en cada elección ${ }^{71}$. La primera demanda -la certificación- favorece el correcto desarrollo del procedimiento de votación por correo, ya que permite el control de la integridad de la correspondencia electoral, así como la posible exigencia de responsabilidades. Con el establecimiento de la gratuidad, por su parte, se fomenta la utilización de esta vía de votación $y$, en consecuencia, el ejercicio del derecho de sufragio.

Estos son los elementos del procedimiento ordinario de votación por correo que nos parecen más positivos. Ahora bien, como hemos adelantado, no todo lo que ha establecido el legislador nos merece un juicio favorable. La regulación actual adolece también, aún después de la importante y plausible reforma de 1992, de ciertas deficiencias que es necesario poner de relieve. Son básicamente las siguientes.

1. La gran complejidad que ha alcanzado el procedimiento en su conjunto. Hay numerosos trámites que cumplir: en primer lugar, el elector debe ir a una oficina de Correos para formular la solicitud de inscripción en el censo electoral; el Servicio de Correos tiene entonces que trasladar la solicitud a la Delegación Provincial de la OCE; a continuación este órgano debe comprobar que el solicitante está efectivamente inscrito en el censo, anotar en el mismo que va a votar por correo, extender el correspondiente certificado y, finalmente, enviárselo al elector junto con las papeletas de votación y demás documentos necesarios para votar; el elector tiene que recibir personalmente este envio, por lo que si no se encuentra en su domicilio deberá acercarse a recogerlo a la Oficina de Correos donde esté depositado; cuando el elector tenga la documentación en su poder y emita su voto debe acudir a una Oficina de Correos para enviarlo por correo certificado a la Mesa Electoral que le corresponda; el Servicio de Correos debe ordenar la correspondencia electoral recibida y distribuirla entre

70 Vid. José L. Ruiz-Navarro Pinar, "Artículo 71", "Artículo 72», "Artículo 73", op. cit., págs. 675-676, 686 y 693; y Enrique ARnALdo AlCUBILLA, El derecho de..., op. cit., págs. $360-361$.

71 Vid., por ejemplo, el artículo 5 de la Orden de 3 de febrero de 2000, por la que se dictan normas para la colaboración de la Entidad Pública Empresarial Correos y Telégrafos en las elecciones al Congreso de los Diputados y al Senado, y en las elecciones al Parlamento de Andalucía (BOE, núm. 36/2000, de 11 de febrero). 
los cientos de oficinas que tiene en todo el país; finalmente, las oficinas de Correos de cada demarcación envían los sobres electorales a las distintas Mesas Electorales.

2. No se ha establecido ningún control externo sobre la recepción y custodia que el Servicio de Correos hace de los sobres electorales que contienen los votos de los electores. No se trata de poner en duda la honorabilidad de los funcionarios de Correos, pero sí de advertir el fuerte contraste que resulta de comparar esta situación con las garantías que ofrece la gestión del voto por personación en la Mesa Electoral: este órgano está constituido por tres electores elegidos por sorteo y además los partidos políticos pueden enviar interventores y apoderados 72 .

3. No se exige acreditar la personalidad del elector en el momento de entregar el voto en Correos, de tal forma que es perfectamente posible que un allegado del elector pueda depositar en su lugar el voto en Correos ${ }^{73}$. Esto supone una inexplicable discordancia con la forma ordinaria de votar en las Mesas Electorales -mediante la identificación del elector en el momento de entregar el sobre de votación-y, además, abre la puerta al menoscabo del principio de personalidad y autenticidad del voto, pues no hay control alguno sobre la posibilidad de que el elector delegue también el acto mismo de la emisión del voto o de que este intermediario manipule el sobre que le ha entregado el elector ${ }^{74}$.

72 Vid. las intervenciones del diputado Souto Paz, del Centro Democrático y Social, tanto en el debate de toma en consideración de la Proposición de Ley de Izquierda Unida origen de la reforma de la LOREG, como en el debate del Pleno sobre el Dictamen emitido por la Comisión Constitucional (Diario de Sesiones del Congreso de los Diputados. IV Legislatura. Pleno, núm. 170, de 3 de marzo de 1992, págs. 8335-8336; y Diario de Sesiones del Congreso de los Diputados. IV Legislatura. Pleno, núm. 194, de 28 de mayo de 1992, pág. 9524).

73 Este fue un tema sumamente polémico durante la tramitación de la reforma de la LOREG de 1992. Vid. el texto de la Proposición de Ley presentada por Izquierda Unida (Boletín Oficial de las Cortes Generales. Congreso de los Diputados, Serie B, núm. 107-1, de 12 de febrero de 1992, pág. 2) y las enmiendas del Partido Popular en el Congreso de los Diputados (Boletín Oficial de las Cortes Generales. Congreso de los Diputados, Serie B, núm. 107-5, de 25 de abril de 1992, pág. 13) y de Izquierda Unida en el Senado (Boletín Oficial de las Cortes Generales. Senado, Serie III B, núm. 23 c, de 22 de junio, pág. 8), así como los Diarios de Sesiones correspondientes.

74 No obstante, conviene puntualizar que la subsanación de esta deficiencia debería ir acompañada de la supresión del requisito legal de que el envío de la documentación electoral por parte de la Delegación Provincial de la OCE tenga que ser recibido personalmente por el elector, pues mantener esta exigencia complicaría excesivamente el procedimiento y no añadiria prácticamente ninguna garantía a la personalidad del voto. 
4. La imposibilidad de revocar la solicitud de votar por correo. EI elector que ha solicitado utilizar esta modalidad de expresión del sufragio no tiene posibilidad alguna de cambiar de decisión y votar personalmente en la Mesa Electoral, tal y como se deduce de los artículos 73.1 y 88.1 y 2 de la LOREG, y han confirmado además la Junta Electoral Central, los Tribunales ordinarios y el propio Tribunal Constitucional 75 . Esto puede suponer una grave y flagrante injusticia para dos tipos de electores: de un lado, aquellos que a pesar de haber solicitado votar de esta forma no lo han hecho finalmente, por el motivo que sea; $y$, de otro lado, los que han llegado a votar por correo pero cuyo sobre electoral no ha llegado a tiempo de ser computado por la Mesa Electoral.

\section{b) Procedimientos especiales}

Nuestro Derecho, como hemos dicho antes, no contempla un único procedimiento para la emisión del voto por correo, sino varios, con el fin de facilitar la utilización de esta modalidad de votación a los miembros de determinados colectivos que en otro caso tendrían muy difícil hacerlo y, en consecuencia, se abstendrian a buen seguro de ejercer su derecho de sufragio. Si al procedimiento que hemos examinado en el apartado anterior se le llama "ordinario", por ser aplicable a todos los ciudadanos, a los que vamos a ver ahora se les denomina "especiales", por tener destinatarios concretos y determinados y entrañar pequeñas variaciones del anterior.

Estos procedimientos están previstos y regulados en distintas normas, de muy diferente rango. En primer lugar, y como es natural, en la LOREG, pero también en muchas otras disposiciones complementarias: el Real Decreto 605/1999, de 16 de abril, de regulación complementaria de los procesos electorales; el Real Decreto 557/1993, de 16 de abril, sobre actuación notarial en el procedimiento de emisión del voto por correo; la Orden del Ministerio de Defensa 116/1999, de 30 de abril, por la que se regula el ejercicio del derecho al voto en los procesos electorales del personal de las Fuerzas Armadas embarcado o en situaciones excepcionales vinculadas con la defensa nacional ${ }^{76}$; la

75 Vid. la Sentencia del Tribunal Constitucional 169/1991, de 19 de julio, especialmente el fundamento jurídico segundo. Vid. también los Acuerdos de la Junta Electoral Central de 16 de junio de 1977, 21 de mayo de 1991, 5 de junio de 1991, 8 de junio de 1991, 2 de junio de 1993, 28 de abril de 1995 y 28 de mayo de 1995 (Apud Enrique Arnaldo Alcubilla y Manuel Delgado-Iribarren Garcia-Campero, Código..., op. cit., págs. 394-395 y 451).

76 Esta Orden se publicó en el BOE núm. 106/1999, de 4 de mayo. 
Orden que el Ministerio de Transportes, Turismo y Comunicaciones dicta en cada proceso electoral para regular la colaboración del Servicio de Correos en el mismo, pues siempre contienen referencias al voto por correo 77; y, por último, las diversas Instrucciones aprobadas hasta la fecha por la Junta Electoral Central 78.

No vamos a entrar ahora en delimitar qué contenido concreto tiene cada una de estas disposiciones, es decir, de qué se ocupa cada una de ellas, sino que únicamente nos interesa conocer el resultado final que se deduce de este conjunto normativo, esto es, saber cuáles son los procedimientos especiales para votar por correo que están actualmente regulados en nuestro Derecho y en qué consisten. $Y$ a este respecto lo primero que hay que decir es que hasta el momento se han establecido cinco procedimientos especiales de voto por correo: el de los ciudadanos que acrediten sufrir enfermedad o incapacidad que les impida acudir personalmente a Correos para hacer su solicitud de voto por correo (artículos 72-c y 73.2 LOREG); el de los electores residentes-ausentes en relación con las elecciones generales, autonómicas y europeas (artículo 75 LOREG); el de este mismo colectivo pero respecto de las elecciones locales (artículo 190 LOREG), el del personal embarcado en los buques de la Armada, de la Marina Mercante española o de la flota pesquera de altura que durante el período electoral toquen puerto en España (artículo 9 del Real Decreto 605/1999, de 16 de abril); y el del personal embarcado en buques de la Armada o perteneciente a unidades militares terrestres o áreas que se encuentre en situaciones excepcionales (Orden del Ministerio de Defensa 116/1999, de 30 de abril). Es además previsible que en un futuro cercano se incorpore otro más, pues el Real Decreto 605/1999, de 16 de abril, de regulación complementaria de los procesos electorales, ha previsto la regulación por el Ministerio de Interior de un procedimiento especial para los policías en misiones de paz en el

77 Así, la Orden de 3 de febrero de 2000, por la que se dictan normas para la colaboración de la Entidad Pública Empresarial Correos y Telégrafos en las elecciones al Congreso de los Diputados y al Senado, y en las elecciones al Parlamento de Andalucía (BOE, núm. 36/2000, de 11 de febrero).

78 Vid. la Instrucción de la Junta Electoral Central de 26 de abril de 1993 sobre la comprobación por la Junta Electoral competente de la concurrencia de las circunstancias a que se refiere el artículo 72-c LOREG; la de 26 de abril de 1993 sobre emisión del certificado médico oficial y gratuito a que se refiere el artículo 72 c LOREG; y la de 20 de abril de 1998 sobre requisitos del voto de los electores inscritos en el Censo Especial de Residentes Ausentes. Sobre estas instrucciones, así como sobre las distintas resoluciones complementarias dictadas por la Junta Electoral Central vid. Enrique ARnaldo AlCubilla y Manuel Delgado-IribarRen GARCIA-CAMPERO, Código..., op. cit., págs. 382 y ss. 
extranjero, aunque a la fecha de hoy el mismo todavía no ha sido aprobado 79 .

Del examen de cada uno de estos procedimientos especiales nos vamos a ocupar a continuación, describiendo con suma brevedad las especialidades que cada uno de ellos introduce en relación con el procedimiento ordinario. No obstante, antes de hacerlo conviene aclarar que no existe obstáculo alguno para que los destinatarios de estos procedimientos ejerzan su sufragio mediante el procedimiento ordinario previsto para el voto por correspondencia en los artículos 72,73 y 88 de la LOREG. Este caso será raro, pero no imposible. Por ejemplo, cabe pensar en el elector inscrito en el Censo de los Españoles Residentes Ausentes (en adelante CERA) que se encuentra en España durante el periodo electoral, pero que desea expresar su sufragio 80 .

1. El procedimiento especial de los ciudadanos que se encuentren en situación de enfermedad 0 incapacidad que les impida formular personalmente la solicitud del certificado de inscripción en el censo, presenta dos únicas especialidades: primera, que la solicitud ha de ser efectuada por otra persona en nombre del elector (artículo 72-c LOREG); y segunda, que en el caso de que el enfermo o imposibilitado no se encuentre en su domicilio en el momento en que el Servicio de Correos va a entregarle la documentación electoral enviada por la Delegación Provincial de la OCE, el mismo representante puede acudir a la Oficina de Correos correspondiente a recogerla (artículo 73.3 LOREG).

Con el fin de evitar el fraude y asegurar en cierta medida los principios de personalidad, libertad e igualdad del voto, la LOREG exige el cumplimiento de ciertos requisitos: primero, la existencia de la enfermedad o incapacidad impeditiva de la formulación personal de la solicitud debe acreditarse por medio de certificación médica oficial y gratuita; segundo, la persona que presenta la solicitud $y$, en su caso,

79 La Disposición Adicional Cuarta del Real Decreto 605/1999 dice así: «Por el Ministerio del Interior se podrán dictar las normas que resulten necesarias para la adaptación de lo previsto en el artículo 9 del presente Real Decreto, a fin de asegurar el ejercicio del derecho al sufragio, mediante el voto por correo, del personal de los Cuerpos y Fuerzas de Seguridad del Estado que se encuentren en las circunstancias establecidas en la disposición adicional tercera".

80 Sobre este caso vid. Ios Acuerdos de la Junta Electoral Central de 21 de septiembre de 1989, 29 de abril de 1991, 6 de junio de 1991, 26 de abril de 1993, 2 de junio de 1994 y 11 de mayo de 1995. Vid. también la Circular aclaratoria de la Junta Electoral Central de 11 de octubre de 1989 (Apud Enrique Arnaldo AlcubiLla y Manuel Delgado-Iribarren Garcia-Campero, Código..., op. cit., págs. 406-407). 
recoge la documentación electoral, ha de estar autorizada notarial o consularmente; tercero, la escritura o documento de poder ha de extenderse individualmente en relación con cada elector; cuarto, una misma persona no puede representar a más de un elector; y quinto $y$ último, la Junta Electoral ha de comprobar en cada caso la concurrencia de las circunstancias anteriores ${ }^{81}$.

Todos estos requisitos han sido desarrollados y completados por el Real Decreto 605/1999, de 16 de abril, de regulación complementaria de los procesos electorales; por el Real Decreto 557/1993, de 16 de abril, sobre actuación notarial en el procedimiento de emisión del voto por correo; y por dos Instrucciones dictadas por la Junta Electoral Central el 26 de abril de 1993: una sobre la comprobación por la Junta Electoral competente de la concurrencia de las circunstancias a que se refiere el artículo 72-c LOREG y otra sobre emisión del certificado médico oficial y gratuito a que se refiere el artículo 72-c LOREG 82 . Lo más destacado de toda esta normativa es que el representante del elector ha de presentar la solicitud en Correos junto con la escritura pública de poder otorgada por notario o cónsul; que dicha escritura ha de incorporar el certificado médico oficial acreditativo de la enfermedad o incapacidad; que la Delegación Provincial de la OCE ha de remitir la solicitud y documentación aneja a la Junta Electoral Provincial para que la examine y decida si procede o no la tramitación antes del sexto día anterior al de la votación; que el certificado médico oficial y gratuito puede extenderlo cualquier facultativo colegiado tanto en papel impreso editado por el Consejo General de Colegios Oficiales de Médicos de España como en papel común 83; y que las actuaciones de notarios y cónsules tienen carácter gratuito ${ }^{84}$.

2. El procedimiento especial de los electores residentesausentes en relación con las elecciones generales, autonómicas y europeas presenta muchas más especialidades que el anterior. Se trata básicamente de las siguientes, detalladas en el artículo 75 de la LOREG:

81 Antes de.la reforma electoral de 1992 la actuación de comprobación de la Junta Electoral era facultativa: "La Junta Electoral correspondiente puede comprobar en cada caso la concurrencia de la circunstancia a que se refiere este apartado"s.

82 Vid. BOE núm. 101/1993, del 28 de abril.

83 La Instrucción de la Junta Electoral Central de 26 de abril de 1993 puntualiza en su artículo 2 que también serán válidos los certificados emitidos en impresos oficiales ordinarios no gratuitos.

84 Así lo ha confirmado la Sentencia del Tribunal Supremo (Sala de lo Contencioso Administrativo) de 27 de marzo de 1998, ante el recurso planteado por el Colegio Notarial de Burgos. 
- El procedimiento se inicia de oficio por parte de las Delegaciones Provinciales de la OCE, las cuales envían a cada elector inscrito en el CERA los documentos precisos para votar (el certificado de inscripción en el censo, las papeletas electorales, etc.).

- El envío de esta documentación por la Delegación Provincial de la OCE ha de realizarse al domicilio que figura en el censo, sin estar previsto que el elector pueda designar otro distinto.

- Dicho envío ha de hacerse por correo certificado, como en el procedimiento ordinario, pero sin exigirse en este caso que la recepción se haga de forma personal por el elector 85 .

- Los electores, tras ejercer su voto de acuerdo con lo dispuesto en el procedimiento ordinario ${ }^{86}$, han de remitir el sobre electoral a la Junta Electoral competente para su escrutinio 87. Esta Junta será la Junta Electoral Provincial, salvo en el caso de las elecciones autonómicas en que habrá que estarse a lo dispuesto en su normativa específica 88 .

- El sobre electoral ha de ser enviado no más tarde del día anterior al de la votación. La LOREG indica que es uindispensable para la validez de estos votos que conste claramente en el sobre mencionado un matasellos u otra inscripción oficial de una Oficina de Correos del Estado en cuestión... que certifi-

85 Así lo ha confirmado la Junta Electoral Central. Vid. el Acuerdo de 2 de junio de 1993 (Apud Enrique Arnaldo Alcubilla y Manuel Delgado-Iribarren GarciaCampero, Código..., op. cit., pág. 406).

86 Esto supone que el elector debe escoger o, en su caso, rellenar la papeleta de voto, introducirla en el sobre de votación y meter este sobre junto con el certificado de inscripción en el censo en el sobre dirigido al órgano escrutador. En este punto es preciso poner de relieve que la Junta Electoral Central admitió en un principio, y de forma sorprendente, la validez de los sobres electorales que no incluyeran el certificado de inscripción en el censo, pero luego tuvo que cambiar de criterio ante los graves problemas que esta situación causaba a los principios de personalidad y autenticidad del voto. A este respecto vid. la Instrucción de la Junta Electoral Central de 20 de abril de 1998 sobre requisitos del voto de los electores inscritos en el Censo Especial de Residentes Ausentes, que rectifica la de 3 de noviembre de 1989.

87 La Ley exige expresamente que el envío del sobre electoral se haga por correo certificado, como en el procedimiento ordinario, pero la Junta Electoral Central ha aceptado la validez del voto ordinario, siempre que conste fehacientemente el sello de la Oficina de Correos correspondiente. Vid. el Acuerdo de la Junta Electoral Central de 2 de junio de 1994 (Apud Enrique Arnaldo AlcubiLla y Manuel Delgado-IribarRen Garcia-Campero, Código..., op. cit., pág. 407).

88 Vid. los artículos 75.1, 173 y 223 de la LOREG, así como las distintas leyes electorales aprobadas por las Comunidades Autónomas. 
que, de modo indubitable, el cumplimiento del requisito temporalı 89 .

- La Junta Electoral competente se constituye en Mesa Electoral, con la asistencia de los interventores de las candidaturas concurrentes en la circunscripción, a las ocho horas del día del escrutinio general, es decir, el tercer día siguiente al de la celebración de las elecciones, lo cual da cierto margen de tiempo para recibir los sufragios 90 . A continuación su Presidente procede a introducir en la urna los sobres de votación de los residentes ausentes recibidos hasta ese día y el Secretario anota los nombres de los votantes en la correspondiente lista. Acto seguido la Junta escruta todos estos votos e incorpora los resultados al escrutinio general.

3. El procedimiento especial de los electores residentesausentes en relación con las elecciones locales, regulado en el artículo 190 de la LOREG, tiene más parecido con el procedimiento ordinario que con el que acabamos de examinar, es decir, que con el procedimiento establecido para que este grupo de electores vote en las elecciones generales, autonómicas y europeas. No obstante, existen también evidentes diferencias respecto del procedimiento ordinario:

- Los electores residentes ausentes que deseen votar en las elecciones municipales deben comunicarlo a la correspondiente Delegación Provincial de la OCE «mediante escrito al que se adjuntará fotocopia del Documento Nacional de Identidad o Pasaporten. Este escrito debe presentarse no más tarde del vigésimo quinto día posterior a la convocatoria 91.

- Recibida la comunicación del elector, la Delegación Provincial de la OCE debe remitirle la documentación precisa para poder votar, con la particularidad de que en vez de enviarle las papeletas de las candidaturas que se presentan en el municipio se

89 No obstante, la Junta Electoral Central ha indicado que los sobres recibidos por las Juntas Electorales Provinciales antes del día de la votación son válidos aunque no conste en ellos el matasellos o inscripción a que alude la Ley o aunque aquél esté total o parcialmente ilegible. En este sentido vid. el Acuerdo de la Junta Electoral Central de 28 de mayo de 1995 (Apud Enrique ARNALDO AlCUBILLA y Manuel Delgado-Iribarren Garcia-Campero, Código..., op. cit., pág. 408).

90 Vid. el artículo 103.1 de la LOREG.

91 La Junta Electoral Central ha entendido que este plazo no tiene carácter preclusivo, por lo que las Oficinas Provinciales de la OCE han de tramitar las comunicaciones de estos electores aun cuando se formulen una vez transcurrido dicho plazo (Acuerdo de 21 de mayo de 1991. Apud Enrique ARnaldo AlCubiLla y Manuel Delgado-Iribarren Garcia-Campero, Código..., op. cit., pág. 784). 
le entrega, por motivos de simplificación en la gestión, una papeleta en blanco y una copia de las páginas del Boletín Oficial de la Provincia en el que figuren las candidaturas proclamadas en el Municipio.

- El envío de la documentación por la Delegación Provincial de la OCE ha de hacerse no más tarde del trigésimo segundo día posterior a la convocatoria, sin exigirse -a semejanza del procedimiento anterior- la recepción personal de la misma por el elector ${ }^{92}$.

- El elector escribirá en la papeleta el nombre del partido, federación, coalición o agrupación de electores a cuya candidatura desee votar y remitirá el sobre electoral conforme a las prescripciones del procedimiento ordinario, lo que supone entre otras cosas que debe enviarlo a la Mesa Electoral correspondiente.

4. Otro procedimiento previsto en la LOREG (artículo 74.2), aunque regulado en el artículo 9 del Real Decreto 605/1999, de 16 de abril, de regulación complementaria de los procesos electorales, es el relativo al personal de los buques de la Armada, marina mercante o flota pesquera de altura, abanderados en España, que haya de permanecer embarcado desde la convocatoria de las elecciones hasta su celebración y que durante dicho período toque puertos, previamente conocidos, en el territorio nacional. Las especialidades respecto del procedimiento son las siguientes:

- El elector debe presentar su solicitud en los servicios de radiotelegrafía del buque y el Comandante o Capitán, o el Oficial en el que expresamente delegue, es quien debe recibir la solicitud y comprobar la identidad del elector de conformidad con lo previsto en el procedimiento ordinario 93 .

- La solicitud del certificado de inscripción del elector en el censo electoral debe cursarse por radiotelegrafía a la correspondiente Delegación Provincial de la OCE, indicando los

92 Este plazo es, sin embargo, imposible de cumplir en el caso de que se interponga un recurso contra la proclamación de las candidaturas. Vid. los artículos 49 y 50 de la LOREG.

93 El apartado cuarto del artículo 9 del Real Decreto 605/1999, de 16 de abril, de regulación complementaria de los procesos electorales, dice así: "A los efectos previstos en los párrafos a) y b) del artículo 72 de la LOREG, los servicios de radiotelegrafía de los buques tendrán la consideración de dependencias delegadas del Servicio de Correos y los Comandantes y Capitanes o el Oficial en el que expresamente deleguen tendrán la consideración de funcionarios encargados de la recepción de la solicitud». 
datos personales, Municipio de residencia en el que está incluido en el censo electoral, nombre del buque en que se encuentra embarcado y puerto o puertos en que tenga prevista su arribada el buque, con indicación de las fechas concretas en que ésta se haya de producir. En caso de que pueda recibir la documentación electoral por medio de otro buque, se indicará también en el radiomensaje el armador, consignatario o buque donde debe ser enviada.

- La Delegación Provincial de la Oficina del Censo Electoral correspondiente, una vez comprobada la inscripción del interesado, procederá a remitir la documentación electoral al puerto o, en su caso, armador, consignatario o buque que el elector hubiese designado y a su nombre.

- El elector enviará, desde cualquiera de los puertos en que el buque atraque, el sobre de votación conforme a las prescripciones del procedimiento ordinario. La única indicación especial es que debe hacerse por correo urgente.

5. El último procedimiento especial establecido en nuestro Derecho, concretamente en la Orden del Ministerio de Defensa 116/1999, de 30 de abril, tiene un destinatario muy singular: el personal embarcado en buques de la Armada o que, perteneciendo a unidades militares terrestres o aéreas, se encuentre destacado fuera del territorio nacional en situaciones excepcionales vinculadas con la defensa nacional y que participe o coopere con las Fuerzas de los países aliados y de organizaciones internacionales en misiones de asistencia humanitaria o mantenimiento de la paz internacional ${ }^{94}$. Las especialidades que presenta son también muy singulares:

- El elector debe presentar su solicitud en los servicios de radiotelegrafía del buque o de las Unidades y el Comandante del buque o Jefe de la Unidad, o el Oficial en el que expresamente delegue, es quien debe recibir la solicitud y comprobar la identidad del elector de conformidad con lo previsto en el procedimiento ordinario ${ }^{95}$.

94 Naturalmente, como indica el artículo 2 de la Orden 116/1999, de 30 de abril, por la que se regula el ejercicio del derecho al voto en los procesos electorales del personal de las Fuerzas Armadas embarcado o en situaciones excepcionales vinculadas con la defensa nacional, el procedimiento "será de aplicación a todo el personal que se encuentre en la situación descrita en el punto primero desde la fecha de convocatoria de las elecciones hasta su celebración".

95 El artículo 7 de la Orden del Ministerio de Defensa 116/1999, de 30 de abril, dice así: «A los efectos previstos en los párrafos a) y b) del art. 72 de la Ley 
- El Comandante del buque o el Jefe de Unidad remitirá la relación de personal que desea ejercer su derecho de sufragio al Director General de Personal del Ministerio de Defensa, quien tramitará las solicitudes del certificado de inscripción en el censo a las correspondientes Delegaciones Provinciales de la Oficina del Censo Electoral a partir de la fecha de la convocatoria y hasta el décimo día anterior a la votación.

- La Delegación Provincial de la Oficina del Censo Electoral correspondiente, una vez comprobada la inscripción del interesado, debe remitir la documentación electoral a la Dirección General de Personal del Ministerio de Defensa para que, por el procedimiento más urgente posible, la haga llegar al destinatario.

- Los electores, una vez ejercido su derecho al voto, entregarán los sobres electorales al Comandante del buque o Jefe de la Unidad, quien los custodiará, garantizando su seguridad, integridad $y$ secreto, hasta que sean recogidos por el encargado de su transporte a territorio nacional.

- La Dirección General de Personal del Ministerio de Defensa hará llegar los votos recibidos al organismo autónomo Correos y Telégrafos, dentro del plazo previsto en el procedimiento ordinario.

Tras este breve examen de los distintos procedimientos especiales de voto por correo establecidos en nuestro Derecho, tan sólo nos resta ofrecer nuestra valoración de los mismos. Se trata de expresar nuestra opinión personal sobre si el establecimiento de estos procedimientos está o no justificado y si su regulación salvaguarda adecuadamente los principios informadores del sufragio.

A este respecto lo primero que hay que indicar es que nos parece una decisión sumamente positiva haber establecido procedimientos especiales de voto por correo para determinados grupos de ciudadanos, es decir, haber adaptado el procedimiento de votación por correo regulado en los artículos 72,73 y 88 de la LOREG a las peculiaridades que presentan ciertos colectivos de ciudadanos, pues en otro caso el voto por correo e, incluso, el propio voto de los mismos, hubiese resul-

Orgánica del Régimen Electoral General, los servicios de radiotelegrafía de los buques o de las Unidades tendrán la consideración de dependencias delegadas del Servicio de Correos, y los Comandantes de buque o Jefes de Unidad o el Oficial en el que expresamente deleguen, así como el Comandante del avión-estafeta y el Director general de Personal del Ministerio de Defensa, la de funcionarios encargados de la recepción de la solicitud.". 
tado imposible de ejercer.

Ahora bien, lo que no nos parece tan positivo es la selección de procedimientos que ha hecho el legislador. En dicha tarea encontramos dos importantes deficiencias.

1. En primer lugar, echamos en falta el establecimiento de un procedimiento específico para un colectivo muy concreto: los españoles que se hallen temporalmente en el extranjero por razones de trabajo, estudios, turismo o cualquier otra. El legislador ha regulado el voto de los que sufran enfermedad o incapacidad que les impida formular personalmente su solicitud, el de los ciudadanos inscritos en el CERA, el del personal embarcado en buques de bandera española que toquen puerto en España durante el período electoral y el de los soldados en el extranjero en misiones de paz, pero se ha olvidado de los ciudadanos inscritos en el censo electoral ordinario que se encuentran en el extranjero durante el período electoral ${ }^{96}$.

La ausencia de un procedimiento especial de votación para estos electores es grave, pues hace que no tengan posibilidad real alguna de votar por correo, cuando se trata precisamente de uno de los colectivos menos discutibles para la utilización de esta modalidad de votación ${ }^{97}$. El procedimiento ordinario de votación por correo les está vedado debido al hecho de que no se han constituido Oficinas de Correos en el extranjero para cursar la solicitud (por ejemplo, habilitando como tales a las Embajadas y Consulados españoles) y a la exigencia legal (artículo 73.2 de la LOREG) de que se tenga que entregar personalmente al elector el envío de la documentación electoral 98 .

2. En segundo término, consideramos absolutamente inadecuado y criticable el establecimiento de dos procedimientos especiales

96 Existe otro colectivo que no cuenta con un procedimiento especial para votar por correo: los ciudadanos embarcados en buques de bandera no española. No obstante, en este caso el olvido está plenamente justificado, pues no existen posibilidades reales de articular el voto por correo de este colectivo. Quizá habría que pensar en introducir para ellos otra modalidad de votación: el voto por medio de representante. A este respecto vid. Ios Acuerdos de la Junta Electoral Central de 12 de mayo de 1993 y 10 de mayo de 1991 (Apud Enrique ARNALDo AlcubILLA y Manuel Delgado-Iribarren Garcia-Campero, Código..., op. cit., pág. 400).

97 Vid. Enrique ARnaldo AlCUBILLA, El derecho de..., op. cit., pág. 376.

98 Vid. los Acuerdos de la Junta Electoral Central de 28 de abril de 1986, 2 de junio de 1986, 29 de abril de 1990 y 12 de mayo de 1993, entre otros (Apud Enrique Arnaldo Alcubilla y Manuel Delgado-Iribarren Garcia-Campero, Código..., op. cit., págs. 387-388 y 392). 
de votación por correo para los electores residentes ausentes: uno para las elecciones generales, autonómicas y europeas, regulado en el artículo 75 de la LOREG, y otro para las elecciones locales, previsto en el artículo 190 de la misma Ley.

Nuestra discrepancia obedece fundamentalmente al hecho de que esta divergencia de procedimientos puede desorientar gravemente al elector que no sabe muy bien cómo actuar en el momento en que llegan las elecciones, especialmente si se produce la convocatoria simultánea de diversos procesos electores. Piénsese tan sólo en el hecho de que si coinciden las elecciones locales con algunas autonómicas, como es frecuente, el elector tendrá que hacer una solicitud para votar en las primeras, pero no en las segundas, pues en este caso recibirá de oficio las papeletas y demás documentación necesaria para votar.

Pero no se trata sólo de esto. Es que, además, no creemos que haya motivo alguno de peso que justifique la configuración de un procedimiento específico de votación por correo para los electores residentes ausentes que deseen votar en las elecciones locales, distinto al que utilizan estos mismos electores para emitir su sufragio postal en las elecciones generales, autonómicas y europeas ${ }^{99}$. Las diferencias establecidas carecen, a mi juicio, de un sólido fundamento, es decir, de una justificación objetiva y razonable. Por ejemplo, el que el procedimiento se ponga en marcha a solicitud del elector, y no de oficio, se justifica -en palabras de la Ponencia constituida en la Comisión Constitucional del Congreso para informar el Proyecto de LOREG- en la idea de que sólo participen aquellos electores uque estén interesados en la problemática de su municipio" ${ }^{100}$. Sin embargo, a nosotros nos parece que el mismo motivo que se alega para las elecciones municipales podría valer también para los demás procesos electorales. No hay motivo para diferenciar el proceso electoral municipal de los demás, cuando la consecuencia de ello es tan grave: la desincentivación de la participación en las urnas.

Por lo que hace al contenido o características de estos procedimientos especiales de votación, son muchas las consideraciones que cabría realizar, pero por evidentes razones de espacio vamos a ser

99 Vid. José L. Ruiz-Navarro Pinar, "Artículo 75", op. cit., pág. 716; Ignacio Astarloa HUARTE-MENDICOA, "Artículo 190", págs. 1642-1645; Enrique ArNaldo AlcuBILLA, El derecho de..., op. cit., págs. 354 y ss.; y Pablo SANTOLAYA MACHETTI, Manual de..., op. cit., págs. 154-156. cit., pág. 385.

100 Vid. CORTES GENERALES, Ley Orgánica del Régimen Electoral...., op. 
sumamente escuetos. Nos vamos a limitar tan sólo a señalar de cada procedimiento el elemento que nos parece más endeble ${ }^{101}$. Estos elementos críticos son los siguientes 102 .

1. En primer lugar, queremos referirnos a la extraordinaria complejidad que ha alcanzado el procedimiento especial de voto por correo de los ciudadanos que se encuentren en situación de enfermedad o incapacidad que les impida formular personalmente la solicitud del certificado de inscripción en el censo. Obsérvese que un sólo paso, la solicitud del certificado, implica los siguientes trámites: el elector ha de llamar a un médico para que certifique su enfermedad o incapacidad; luego ha de solicitar la presencia de un notario para que autorice el apoderamiento; a continuación el representante del enfermo tiene que desplazarse a Correos a solicitar el certificado de inscripción en el censo; el Servicio de Correos traslada toda la documentación a la Delegación Provincial de la OCE; ésta debe remitir a su vez la documentación, antes de tramitarla, a la Junta Electoral Provincial; este órgano debe comprobar la concurrencia de las circunstancias exigidas por la Ley y cuando adopte una decisión debe comunicársela a la Delegación Provincial de la OCE y remitirle de nuevo la documentación; finalmente esta Delegación Provincial deberá enviar al elector la documentación necesaria para el voto por correo o bien notificarle la decisión contraria de la tramitación de la solicitud.

Esta compleja tramitación atenta claramente contra los principios de facilitación y de efectividad del voto, pues no cabe duda de que,

101 En otro trabajo, en avanzado curso de elaboración, nos ocuparemos de examinar con más detalle los distintos procedimientos especiales de votación.

102 Un aspecto sumamente criticable, pero en el que no vamos a entrar por pertenecer más al terreno del censo electoral que al del voto por correo, es el de la amplia libertad que tienen actualmente los electores residentes ausentes que viven en el extranjero para designar el municipio en el que desean inscribirse (vid. la Disposición Tercera de la Orden del Ministerio de Economía y Hacienda de 24 de abril de 1996, por la que se dictan normas para la actualización mensual del censo electoral. BOE núm. 102/1996, de 27 de abril). Esta libertad puede ser utilizada, e incluso hay fuertes sospechas de que ya lo ha sido en alguna ocasión, para producir la inscripción masiva de electores adictos a un concreto partido en determinados municipios estratégicos o de resultado electoral previsiblemente ajustado, consiguiendo con ello alterar fraudulentamente la relación de fuerzas y, por consiguiente, la distribución de escaños. Éste es precisamente el trasfondo del llamado "caso Formentera", relativo a la presunta organización por determinados miembros"de un partido político de la inscripción de decenas de ciudadanos españoles residentes en Argentina en el municipio de Formentera sin tener ninguna vinculación con el mismo. Ya ha habido investigaciones por parte del Parlamento de las Islas Baleares y actualmente existen investigaciones judiciales en marcha para depurar tres posibles delitos: fraude electoral, falsedad documental y malversación de caudales públicos. 
por un lado, muchos electores se desanimarán y no lo utilizarán y que, por otro lado, queda muy poco tiempo para llevar a cabo el resto del procedimiento: envío de la documentación electoral al elector, recogida en su caso de la documentación electoral en Correos por el representante del elector, emisión del voto por el elector, remisión del voto por correo certificado por el representante del elector y entrega de los votos por el Servicio de Correos a las distintas Mesas Electorales antes de las ocho horas del día de las elecciones. Además, la complejidad de que hablamos no ha redundado en una protección estimable de otros principios del sufragio. Así, no existe garantía alguna de que la persona que ha emitido el voto sea realmente el elector y no su representante o de que éste no va a manipular el voto emitido por el elector tergiversando la voluntad del mismo.

2. En segundo término, hay que destacar la absoluta falta de control de la personalidad del elector en el procedimiento regulado en el artículo 75 de la LOREG, es decir, el de los ciudadanos inscritos en el CERA que ejercen su sufragio en las elecciones generales, autonómicas y europeas. En el procedimiento ordinario el elector debe acreditar su identidad en dos momentos distintos: en el momento en que el elector presenta su solicitud para votar por correo y en el instante en que recibe de la Delegación Provincial de la OCE la documentación electoral necesaria para ejercer su sufragio. En cambio, en el procedimiento del artículo 75 LOREG la personalidad del elector no se controla nunca: en primer lugar, porque no hay solicitud del elector sino que la Delegación Provincial de la OCE envía de oficio el certificado de inscripción en el censo 103; y en segundo lugar, porque no se exige la recepción personal por el elector de la documentación.

Esta regulación puede dar lugar, evidentemente, a numerosos fraudes, sobre todo si tenemos en cuenta que el CERA no está todo lo actualizado que sería de desear. Como se ha puesto de manifiesto en diversas elecciones, muchos electores a los que se envía la documentación electoral ya han fallecido o ya no viven en el domicilio que consta en el censo. Es perfectamente posible, por ello, que unas personas voten en lugar de otras, poniendo en serio peligro la limpieza de las elecciones y con ello la legitimidad del poder en caso de resultados electorales ajustados. La cuestión ha sido recientemente objeto de

103 En el procedimiento de votación por correo para los electores residentes ausentes que deseen votar en las elecciones locales el control de la personalidad no es mucho mayor, pero por lo menos se exige en el momento de hacer la solicitud que el interesado incluya fotocopia de su Documento Nacional de Identidad o Pasaporte (artículo 190.1 LOREG). 
atención por los políticos, dando lugar a fuertes debates parlamentarios. Así el diputado Quintana González, del Bloque Nacionalista Gallego, ha podido señalar:

"Aquí se ha dicho en más de una ocasión que en algún proceso electoral habían votado los muertos. Yo no quiero entrar en el caso particular de la disquisición de cómo eso se produce o no se produce, pero lo cierto es que tal cual está el censo de residentes ausentes es tremendamente fácil que eso ocurra. Fijense ustedes que una persona pudo realizar cualquier trámite administrativo en un consulado y morir a la semana siguiente. Esa persona, aunque falleciera, puede ser incluido en el censo de residentes ausentes, puesto que él no tiene que hacer ningún trámite administrativo para estarlo, sino que simplemente por haber pasado por el consulado va a estar en el censo de residentes ausentes. Una vez que está en el censo, aunque haya fallecido, recibirá en su casa los sobres de votación, puesto que tampoco tiene que pedirlos, y si después en ese domicilio existe un pillo, una persona con falta de ética democrática, podrá, en nombre del fallecido, enviar un sobre certificado y, por lo tanto, habrá votado por el fallecido y no se habrá vulnerado la ley "stricto sensu", independientemente de que se haya vulnerado el carácter democrático que todo proceso electoral tiene. Por lo tanto, señorías, estamos ante un marco legal que puede propiciar y propicia de facto un sistema de votación falto de transparencia, de equidad $y$, en consecuencia, de contenido democrático. En definitiva, es urgente que pongamos en funcionamiento los mecanismos necesarios para poder corregir esto» 104.

3. Otro elemento claramente criticable, sobre el que ya se ha pronunciado con carácter genérico la doctrina en alguna ocasión ${ }^{105}$, es el deficiente diseño que se ha dado al procedimiento especial de voto por correo de los electores residentes ausentes que deseen votar en las elecciones locales. Existen, a nuestro entender, serias incompatibilidades entre los elementos que lo definen, con graves consecuencias sobre algunos de los principios básicos del sufragio.

La primera fricción surge entre la forma de rellenar las papeletas electorales y la elección del órgano que ha de hacer el escrutinio de las mismas, y tiene como damnificado al principio de secreto del voto. La incompatibilidad parece clara: de un lado, al elector no se le entregan las papeletas de las distintas candidaturas que se presentan en el municipio, como es lo habitual, sino una papeleta en blanco y una copia de

104 Vid. Diario de Sesiones del Senado. VII Legislatura. Pleno, núm. 47, de 23 de mayo de 2001, pág. 2615.

105 Vid. Ignacio Astarloa HuARTE-MendicoA, "Artículo 190», págs. 1642-1645; Enrique Arnaldo AlCUBILla, El derecho de..., op. cit., págs. 354 y ss.; y Pablo SantoLAYA MACHETTI, Manual de..., op. cit., págs. 154-156. 
la página del Boletín Oficial de la Provincia en el que figuren las candidaturas proclamadas, para que escriba en dicha papeleta uel nombre del partido, federación, coalición o agrupación a cuya candidatura desee votar"; $y$ de otro lado, el escrutinio de estas papeletas manuscritas no se realiza por las Juntas Electorales, como en el procedimiento del artículo 75 de la LOREG (voto de los electores residentes ausentes en elecciones generales, autonómicas y europeas), sino por las Mesas Electorales de forma conjunta con los votos de los residentes en España. Si a estos elementos normativos añadimos el dato de la gran cantidad de pequeños municipios existentes en España, de que las Mesas Electorales no suelen tener más de 1.500 electores inscritos y de que los electores residentes ausentes que ejercen su voto no suelen llegar a una tercera parte, es posible concluir que será frecuente la existencia de Mesas Electorales en las que sólo se hayan emitido una o dos papeletas manuscritas, con lo que la salvaguardia del secreto del voto de estos electores queda seriamente comprometido.

Otra grave contradicción se encuentra entre la exigencia de que el procedimiento se ponga en marcha a solicitud expresa del elector y el requisito de que el elector tenga que emitir su voto no más allá del tercer día previo a la fecha prevista para la celebración de las elecciones, con el fin de que pueda ser computado por las Mesas Electorales y no por las Juntas Electorales Provinciales. Ello supone que los españoles inscritos en el CERA que deseen votar en las elecciones locales deben enviar por correo, desde su país de residencia, su solicitud de voto; ésta solicitud tiene que llegar a la correspondiente Delegación Provincial de la OCE; cuando este órgano comprueba que el elector está inscrito en el CERA debe enviarle, desde España, el pertinente certificado de inscripción junto con el resto de la documentación necesaria para votar; en el momento en que el elector recibe la documentación y emite su voto debe remitirlo por correo desde su país lo más tardar tres días antes de la votación; $y$, por último, por si fuera poco, el voto tiene que llegar a España y estar en poder de la correspondiente Mesa Electoral antes de las 20 horas del día de la votación. Nos parece que esta articulación sólo puede conducir a la desincentivación del voto y a algo todavía peor: al riesgo cierto de la inutilidad del voto ya ejercido, pues obsérvese que el elector tiene que estar atento a mandar su solicitud con prontitud, que tienen que intervenir varios servicios de correos, que en algunos países son muy deficientes ${ }^{106}$, y que el plazo para todo ello no es muy amplio.

106 En relación con las deficiencias en la tramitación del voto por servicios de correos extranjeros vid. Pablo Santolaya MACHETti, Manual de..., op. cit., pág. 156. 
Lo que no sabemos muy bien es por qué ha querido el legislador que esto sea así, cuando en el caso del voto de los emigrantes en las elecciones generales, autonómicas y europeas no lo ha considerado oportuno. En este supuesto, como ya sabemos, el procedimiento se inicia de oficio, los votos pueden remitirse hasta el día anterior al de la votación y existe además de plazo hasta el tercer día posterior al de las elecciones para que sea recibido válidamente por el órgano escrutador. No nos gusta hacer juicios de intenciones, pero parece que todo está previsto para devaluar la participación de los emigrantes en la política municipal. El legislador parece ver con escasa simpatía esta participación, pero dado el elevado coste político que tenía no reconocer a los residentes ausentes el derecho de voto en las elecciones locales (opción perfectamente posible a la vista del artículo 68.5 de la Constitución 107 ) ha optado por ponerles las cosas difíciles 108.

4. En cuarto lugar, hay que aludir a la falta de previsión del apoyo institucional que resulta necesario para facilitar el correcto desarrollo del procedimiento previsto en el artículo 9 del Real Decreto $605 / 1999$ para el voto por correo de los marineros que hayan de permanecer embarcados durante el período electoral en buques españoles que toquen puerto en el territorio nacional. Ni está previsto reglamentariamente desarrollar alguna campaña de información específica sobre estos ciudadanos para que no se les pase el plazo para solicitar el voto por correo ${ }^{109}$, ni, lo que es más relevante, se ha organizado la actuación de ningún órgano intermedio que sirva de enlace para las comunicaciones entre los Comandantes de los buques y las distintas Delegaciones Provinciales de la OCE.

107 El artículo 68.5 impone al Estado la obligación de facilitar el ejercicio del derecho de sufragio a los españoles que se encuentren fuera del territorio de España, pero hay que tener en cuenta que este artículo solo se ocupa de las elecciones al Congreso de los Diputados.

108 Sobre el reconocimiento y ejercicio del derecho de sufragio por parte de los españoles residentes en el extranjero vid. la magnífica monografía de Enrique ARNALDo AlCUBiLla, El derecho de..., op. cit., especialmente págs. 261 y ss.

109 Tan solo contamos con la genérica previsión legal de realización de campañas institucionales destinadas a informar sobre los trámites del voto por correo: "Los poderes públicos que en virtud de su competencia legal hayan convocado un proceso electoral pueden realizar durante el período electoral una campaña de carácter institucional destinada a informar a los ciudadanos sobre la fecha de la votación, el procedimiento para votar y los requisitos y trámite del voto por correo, sin influir, en ningún caso, en la orientación del voto de los electores. Esta publicidad institucional se realizará en espacios gratuitos de los medios de comunicación social de titularidad pública del ámbito territorial correspondiente al proceso electoral de que se trate, suficientes para alcanzar los objetivos de esta campañan. 
Así, por ejemplo, en el caso de que en un buque viajen 80 marineros pertenecientes a 40 provincias distintas, el Comandante del buque se verá obligado a contactar con otras tantas Delegaciones Provinciales de la OCE, cuando lo mejor sería, sin duda, que lo hiciera con un único órgano y que éste se encargara de canalizar la información a las distintas Delegaciones Provinciales de la OCE.

5. Finalmente, respecto del procedimiento regulado en la Orden del Ministerio de Defensa 116/1999 para el voto por correo de los marineros y soldados que se encuentren fuera del territorio nacional en situaciones excepcionales, hay que decir que nos parece muy criticable el hecho de que no se haya establecido ninguna clase de control interno o externo sobre la recepción y custodia de los votos por parte tanto de los Comandantes de los buques o Jefes de Unidad, como de la Dirección General de Personal del Ministerio de Defensa. Los primeros actúan en solitario $y$, además, se encuentran en estrecha dependencia del Gobierno; la Dirección General de Personal presenta, por su parte, todavía más problemas, pues la ocupación de su cúspide por personas nombradas directamente por el Gobierno le concede un elevado perfil político.

Ninguno de ellos reúne, por tanto, las más elementales garantías de neutralidad e independencia propias de la Administración Electoral. Y si estas garantías son necesarias en todo órgano que tenga tareas administrativas que cumplir en el proceso electoral, resultan absolutamente imprescindibles cuando se trata de una cuestión tan sensible como la gestión y custodia de los votos de los ciudadanos 110 .

\section{C) Régimen sancionador}

El estudio del régimen jurídico del voto por correo no se agota con el examen del campo de aplicación que tiene esta modalidad de votación y de los procedimientos establecidos para su ejercicio. El cuadro quedaría sensiblemente incompleto si no aludiéramos, aunque sea de forma breve, a las normas penales que garantizan el cumplimiento de la regulación estudiada.

Este régimen sancionador se encuentra recogido en el Capítulo VIII del Título I de la LOREG, consagrado a los «delitos e infracciones electo-

110 Sobre la necesaria independencia de los órganos encargados de la administración y control del proceso electoral vid. W. J. M. MACKENCIE, Elecciones..., op. cit., págs. 109-110. 
rales", y se halla integrado por dos disposiciones específicas: el artículo 139.8, que castiga con la pena de arresto mayor y multa de 30.000 a 300.000 pesetas a los funcionarios públicos que dolosamente uincumplan los trámites establecidos por el voto por correspondencian; y el artículo 141.1, que sanciona con las mismas penas a los particulares que hagan lo mismo.

La existencia de estas disposiciones se encuentra, a nuestro juicio, absolutamente justificada, dada la gran relevancia que para el correcto desarrollo de las elecciones tiene el cumplimiento de las distintas normas que disciplinan la emisión del voto ${ }^{111}$. El legislador ha considerado que la regulación del voto por correo es de tal importancia para la democracia que su infracción debe acarrear la reacción más dura de nuestro ordenamiento jurídico: la intervención del Derecho Penal para castigar a los culpables ${ }^{112}$.

El régimen penal en materia de voto por correo plantea numerosas cuestiones de interés. No obstante, por evidentes razones de simplificación en el análisis, nos vamos a limitar a continuación a señalar muy brevemente las cuatro notas que nos parecen más relevantes y dignas de consideración.

- La conducta tipificada en los artículos 139.8 y 141.1 de la LOREG está descrita con gran amplitud y generalidad: incumplir (artículo 139) o vulnerar (artículo 141) «los trámites establecidos para el voto por correspondencia». No obstante, el Tribunal Supremo ha puntualizado con indiscutible acierto que sólo alcanzan carácter penal los incumplimientos de "trámites importantes, esenciales y fundamentales... que alteren o pretendan alterar el curso democrático mediante la manipulación de la intención del voto, aunque sea de una sola persona" 113.

111 En el mismo sentido vid. José L. Peñaranda Ramos, "Artículo 139", en

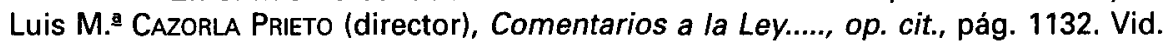
también las Sentencias del Tribunal Supremo (Sala Segunda) de 24 de junio de 1993 y de 18 de julio de 1997.

112 Por el contrario, la legislación electoral anterior a la LOREG, constituida básicamente por el Real Decreto Ley 20/1977, de 18 de marzo, sobre normas electorales, no contemplaba sanción penal alguna en materia de voto por correo.

113 El texto entrecomillado está sacado del fundamento jurídico cuarto Sentencia del Tribunal Supremo (Sala Segunda) de 23 de febrero de 1994: “...si el legislador se refiere al incumplimiento de trámites, obviamente tiene que estar pensando en trámites importantes, esenciales y fundamentales. Tiene que estar pensando en incumplimientos graves que alteren o pretendan alterar el curso democrático mediante la manipulación de la intención del voto, aunque sea de una sola persona. No puede pues referirse a trámites inocuos o al menos baladíes e intranscendentes como los en este caso incumplidos». 
- El sujeto activo de la vulneración de los trámites del voto por correo son tanto los funcionarios públicos -en el sentido que a esta expresión le ha dado el artículo 135 de la LOREG 114_ como los particulares. Hasta la reforma electoral de 1992 esto no era, sin embargo, así, pues las infracciones realizadas por particulares no estaban tipificadas penalmente 115 .

- La LOREG sólo castiga penalmente las infracciones dolosas de los trámites del voto por correo ${ }^{116}$. La Ley es absolutamente clara al respecto, pues emplea de forma expresa el término "dolosamente". Las vulneraciones cometidas por imprudencia son simples ilícitos administrativos castigados por las Juntas Electorales competentes conforme a lo previsto en el artículo 153.1 de la misma Ley 117.

- La sanción por infringir la regulación del voto por correo consiste, según los artículos 139.8 y 141.1 de la LOREG, en la imposición de "la pena de arresto mayor y multa de 30.000 a 300.000 pesetas» 118 . Además, hay que añadir la de inhabilitación especial para el derecho de sufragio, pues de acuerdo con el artículo 137 de la misma norma, esta pena se impone necesariamente a todos los delitos electorales 119.

114 El artículo 135.1 da la siguiente definición de funcionario público a los efectos de dicha Ley: "A los efectos de este capítulo son funcionarios públicos los que tengan esta consideración según el Código Penal, quienes desempeñen alguna función pública relacionada con las elecciones, y en particular los Presidentes y Vocales de las Juntas Electorales, los Presidentes, Vocales e Interventores de las Mesas Electorales y los correspondientes suplentes".

115 El Tribunal Supremo ha confirmado en varias sentencias que las vulneraciones de los trámites del voto por correo realizadas por particulares eran atípicas hasta 1992. Vid., por ejemplo, la Sentencia del Tribunal Supremo (Sala Segunda) de 5 de mayo de 1994.

116 En este sentido vid. la Sentencia del Tribunal Supremo (Sala Segunda) de 23 de febrero de 1994.

117 El artículo 153.1 de la LOREG dice asi: "Toda infracción de las normas obligatorias establecidas en la presente Ley que no constituya delito será sancionada por la Junta Electoral competente. La multa será de 20.000 a 200.000 pesetas si se trata de autoridades o funcionarios y de 5.000 a 100.000 si se realiza por particulares".

118 Hoy día, tras la aprobación del nuevo Código Penal, esta pena debe entenderse sustituida por la de arresto de doce a quince fines de semana. Vid. el apartado 1-e) de la Disposición Adicional Undécima de la Ley 10/1995, de 23 de noviembre, del Código Penal.

119 El artículo 137 de la LOREG dice asi: “Por todos los delitos a que se refiere este capítulo se impondrá, además de la pena señalada en los artículos siguientes, la de inhabilitación especial para el derecho de sufragio pasivon. Hasta 


\section{CONSIDERACIONES FINALES Y PROPUESTAS DE REFORMA}

Una vez que hemos visto el sólido fundamento constitucional del voto por correo, su carácter contingente, los límites que el legislador tiene a la hora de regularlo, el amplio campo de aplicación que se le ha reconocido, los procedimientos establecidos para su ejercicio y las normas penales que lo garantizan, parece llegado el momento de emitir un juicio final sobre esta forma de votación. No se trata de valorar cada uno de los elementos que integran esta regulación, sino de integrar de forma genérica todos los conocimientos examinados y responder a la pregunta que nos planteamos al comenzar el trabajo: si es o no necesario proceder a la reforma del régimen actual de voto por correo, $y$, en su caso, en qué sentido habría que llevar a cabo dicha reforma.

A este respecto lo primero que hay que indicar es que el voto por correo es una modalidad de votación que ha permitido ejercer eficazmente su sufragio, elección tras elección, a centenares de miles de personas que no tenían posibilidad alguna de acercarse a las urnas el día de la votación o que sufrían serias dificultades para ello ${ }^{120}$. No cabe duda de que sin el establecimiento del voto por correo en nuestro Derecho la mayoría de estas personas no habrían podido participar en las elecciones, con lo que ello hubiera supuesto de frustración personal para ellas por no poder ejercer su derecho $y$ de pérdida de legitimidad para el sistema democrático, basado precisamente en la más amplia participación de los ciudadanos.

Ahora bien, el reconocimiento de este importante logro no es obstáculo para advertir sus deficiencias. Las tiene y muchas, como hemos puesto de relieve a lo largo del apartado anterior. No obstante ahora, desde una perspectiva general y de conjunto, y que tiene como punto de referencia básico la finalidad de la institución y los principios informadores del sufragio, tan sólo nos queremos detener en dos consideraciones de carácter crítico.

a) En primer lugar, existen una serie de colectivos ciudadanos para los que el voto por correo no representa una alternativa real de

la entrada en vigor de la Ley 10/1995, de 23 de noviembre, del Código Penal, la inhabilitación afectaba también al sufragio activo (Disposición Derogatoria Única, apartado 1-f).

120 Entre electores inscritos en el censo ordinario y electores inscritos en el CERA vienen utilizando el sistema de voto por correo entre el 2 y el $3 \%$ de los electores que expresan su sufragio. Por ejemplo, en las elecciones generales dicho porcentaje fue del 2,66 (Fuente: Ministerio del Interior, Elecciones a Cortes Generales, 1996). 
votación. Es el caso de los españoles que se encuentran temporalmente en el extranjero; de los marineros embarcados en buques no abanderados en España; de los marineros abanderados en España, pero que no toquen puerto español durante el período hábil para emitir su sufragio; de las personas que están desarrollando funciones lejos de su domicilio habitual y que no tienen un domicilio fijo y determinable durante el período electoral; de los españoles residentes ausentes que han cambiado de domicilio respecto a la última actualización del CERA (pues la documentación electoral se envía de oficio a aquél); e incluso de aquellos ciudadanos que tras acabar el plazo de solicitud de voto por correo caen enfermos o se desplazan inesperadamente fuera de su localidad.

Todos estos ciudadanos no pueden, por razones obvias, expresar su voto personalmente en la Mesa Electoral que les corresponde, pero tampoco pueden hacerlo por correo, pues en todos los casos señalados existe algún obstáculo material o legal que lo impide en la práctica. Esto supone que lamentablemente estas personas verán pasar el día de las elecciones sin poder tener más participación en el mismo que la de espectadores, tal vez resignados, tal vez disgustados.

b) La segunda consideración que queríamos realizar es que en el voto por correo no se ha llegado al mismo nivel de protección de las condiciones básicas del sufragio que en el voto ejercido directamente en la Mesa Electoral. Mientras que en éste la garantía es prácticamente total 121, en aquél no lo es, sufriendo la mayoría de dichas condiciones algún tipo de menoscabo, de mayor o menor grado según los procedimientos.

Pongamos el ejemplo del principio de personalidad del sufragio: en el voto ejercido en la Mesa no hay duda alguna de la personalidad del elector, pues éste, antes de entregar su voto al Presidente para que lo introduzca en la urna, debe acreditar su identidad mediante la exhibición del Documento Nacional de Identidad, Pasaporte o Carnet de conducir 122; en cambio, en el voto por correo no ocurre así, pues la LOREG no exige en ningún caso que el elector tenga que entregar personalmente el sobre electoral en Correos o en la dependencia que, en

121 Tan solo encontramos una deficiencia en la protección de los principios de personalidad, libertad y secreto del voto: que no se haya impuesto al elector, como sucede en otros países de nuestro entorno, la obligación de pasar necesariamente por la cabina electoral antes de entregar el sobre de votación en la Mesa Electoral.

122 Vid. los artículos 85,86 y 87 de la LOREG. 
su caso, haga de tal, por lo que no hay constancia alguna de que el elector es realmente la persona que ha votado. Veamos otro ejemplo, el del principio de efectividad del voto: en el sufragio emitido por personación en la Mesa Electoral hay casi $100 \%$ de posibilidades de que el voto introducido en la urna va a ser computado, pues salvo causa de fuerza mayor no hay riesgo que lo impida; no existe, sin embargo, la misma seguridad cuando el voto se ejerce por correo, ya que es posible que por problemas de plazo y de distribución no llegue al órgano escrutador a tiempo de ser contabilizado, y así lo corroboran las estadísticas elección tras elección ${ }^{123}$.

En definitiva, es posible concluir que el voto por correo, tal y como está regulado en la actualidad en nuestro ordenamiento, es una modalidad de votación sumamente útil para muchos ciudadanos, pero que no es una alternativa real y efectiva para ciertos colectivos ciudadanos y que los principios del sufragio no han alcanzado el mismo nivel de protección que en el voto directo en las Mesas Electorales.

Ante esta situación surge con fuerza la posibilidad de una reforma, habida cuenta el amplio margen de actuación que permite la ordenación del procedimiento de votación por correo. No es éste, como es evidente, el lugar oportuno, de hacer una articulación detallada y sistemática de todas las modificaciones que sería conveniente realizar, pues ello excedería ampliamente los límites espaciales fijados para este trabajo $y$, además, la mayoría de las medidas son muy fáciles de deducir de la crítica que hemos hecho en el capítulo anterior a los distintos puntos de la regulación. Sin embargo, sí es posible apuntar la conveniencia de introducir ciertas modificaciones de carácter general.

- Que sea obligatoria la constitución de oficinas de correos específicas en los centros públicos o privados de internamiento (hospitales, asilos de ancianos, prisiones, conventos de clausura, etc.). La LOREG no lo prevé, como se ha propuesto en alguna ocasión ${ }^{124}$, pero hacerlo facilitaría enormemente el sufragio de estos colectivos. Igualmente sería conveniente constituir Oficinas de Correos en el extranjero (por ejemplo, habilitando como tales a las Embajadas y Con-

123 Vid. Pablo Santolaya Machetti, Manual de..., op. cit., págs. 152-153.

124 Así lo propuso la Junta Electoral Central en su Informe de 1992 sobre el voto por correo. $Y$ así pensaron hacerlo el Partido Socialista y el Partido Popular con ocasión de la tramitación de la Ley Orgánica 6/1992, de 2 de noviembre (Vid. las enmiendas núms. 5 y 12 en el Boletín Oficial de las Cortes Generales. Congreso de los Diputados, Serie B, núm. 107-5, de 25 de abril de 1992, págs. 11 y 13). 
sulados españoles) para que los electores que se hallen temporalmente en el extranjero -por razones de trabajo, estudios, turismo o cualquier otra- tengan alguna posibilidad de votar en las elecciones 125 .

- Que los votos por correo sean escrutados en todos los casos por las Juntas Electorales, o mejor, por Mesas Electorales especiales constituidas bajo el control de las Juntas Electorales y los interventores de los partidos políticos ${ }^{126}$. Si el escrutinio de cada circunscripción pudiera ser centralizado en Mesas Electorales específicas se conseguiría reducir considerablemente el trasiego de votos por todo el territorio nacional, el cual no hace más que poner en peligro la integridad de los envíos y la efectividad de su recepción en tiempo hábil. Así, por ejemplo, en las elecciones al Congreso de los Diputados, no habría que llevar los votos por correo el día de las elecciones a las miles de Mesas Electorales dispersas por todo el territorio nacional, sino únicamente a los 52 locales constituidos en las capitales de cada circunscripción, donde serían contabilizados por las Mesas que fuera necesario establecer según el volumen de votos.

- Que el procedimiento establecido en el artículo 75 de la LOREG para que los electores inscritos en el CERA voten en las elecciones generales, autonómicas y europeas se aplique también a las elecciones locales. Esto supone eliminar el procedimiento especial de votación por correo previsto en el artículo 190 de la LOREG para estas últimas elecciones y aplicar a todos los residentes ausentes la posibilidad de entregar su sobre de votación directamente en los consulados y embajadas españoles o de votar por correo según el procedimiento especial previsto en el artículo 75127.

125 Vid. los Acuerdos de la Junta Electoral Central de 28 de abril de 1986, 2 de junio de 1986, 29 de abril de 1990 y 12 de mayo de 1993, entre otros (Apud Enrique Arnaldo Alcubilla y Manuel Delgado-Iribarren Garcia-Campero, Código..., op. cit., págs. 387-388 y 392). Vid. también Enrique ARNALDo AlcubILLA, El derecho de..., op. cit., pág. 376.

126 Actualmente los votos por correo emitidos por los electores inscritos en el censo electoral ordinario y por los electores inscritos en el CERA en el caso de elecciones locales son escrutados por las correspondientes Mesas Electorales, mientras que los votos expresados por los electores inscritos en el CERA en las elecciones generales, autonómicas y europeas lo son por las Juntas Electorales competentes.

127 Vid. Pablo Santolaya Machetti, Manual de..., op. cit., págs. 154-156; y Enrique ARnALDo AlCUBILla, El derecho de..., op. cit., págs. 354 y ss. 
- Que se exija en todos los procedimientos la obligación de acreditar la identidad del elector en el momento de hacer entrega de su sobre de votación. La Ley no lo prevé en ningún caso, pero nos parece un elemento fundamental para asegurar la personalidad del sufragio. Esto puede plantear problemas respecto al voto de los españoles inscritos en el CERA en algunos paises extranjeros con los que no sea fácil o eficaz establecer convenios para imponer esta exigencia, pero por lo menos en este caso debería exigirse que estos electores introdujeran en el sobre electoral una fotocopia de su Documento Nacional de Identidad y una declaración jurada de que es él quien emite el voto y no otra persona 128 .

- Que los trámites para votar por correo se pongan en marcha de oficio por parte de la OCE y no a solicitud del elector, tal y como sucede actualmente en nuestro país en el caso de los electores residentes ausentes para las elecciones generales, autonómicas y europeas 129 . Esta es una propuesta que podría facilitar el ejercicio del derecho de sufragio y que, aunque plantea ciertos problemas de gestión, creemos que los mismos serían solucionables sin grandes dificultades si hubiera voluntad política para hacerlo ${ }^{130}$. A nuestro juicio, por tanto, y siempre que el voto por correo siga configurado en nuestro Derecho como una opción libre del elector, la OCE debería enviar de oficio este certificado a todos los ciudada-

128 La declaración jurada en materia de voto por correo es una figura presente en algunos países. Vid., por ejemplo, el artículo 36 de la Ley Electoral alemana de 1956. Vid. también sobre su aplicación en nuestro Derecho la enmienda del Partido Popular presentada durante la tramitación en el Congreso de los Diputados de la reforma electoral de 1992 (Boletín Oficial de las Cortes Generales. Congreso de los Diputados, Serie B, núm. 107-5, de 25 de abril de 1992, pág. 13, enmienda núm. 12).

129 La aceptación de esta propuesta requeriría necesariamente controlar la personalidad del elector en el momento en que éste procediera a enviar el voto a la Mesa Electoral correspondiente y, además, que el Servicio de Correos remitiera a la OCE la lista de las personas que han ejercido efectivamente su sufragio por correo, con el fin de que anote en el censo que van a votar por correo y no se incurra en un doble voto.

130 La OCE ya envía en la actualidad a todos los electores su tarjeta censal. Así lo exige el artículo 39.5 LOREG, tras la reforma electoral de 1995: "La Oficina del Censo Electoral remitirá a todos los electores una tarjeta censal con los datos actualizados de su inscripción en el censo electoral y de la Sección y Mesa en la que les corresponde votar y comunicará igualmente a los electores afectados las modificaciones de Secciones, locales o Mesas, a que se refiere el artículo 24 de la presente Ley Orgánica". 
nos, junto con las papeletas de votación y la demás documentación electoral, y que luego cada elector tomara la decisión de votar por correo o no ${ }^{131}$. Si el elector decide votar por correo el beneficio que se consigue es evidente, pues se le ha evitado un engorroso trámite, algo que sin duda favorece su participación electoral. Y si el elector opta por votar en la Mesa Electoral también hay ventajas, pues dispone anticipadamente de las papeletas electorales y el día de las elecciones puede acercarse tranquilamente a su colegio electoral con el sobre de votación en su bolsillo, costumbre ésta bastante extendida en la actualidad, gracias a los envíos postales que hacen los partidos políticos a costa del erario público 132. Además, conviene puntualizar que debería mantenerse la posibilidad de que el elector pueda emitir su solicitud para que le envíen la documentación a otro lugar (por ejemplo, por haber cambiado de residencia, por estar embarcado en un buque de la armada, etc.).

Con la aplicación de estas propuestas creemos que la regulación del voto por correo se acercaría más a la consecución del fin de facilitar la participación electoral para el que nació y que se lograría un mayor cumplimiento de los principios básicos del sufragio. Ahora bien, somos conscientes de que esto tampoco es la panacea. La vía reformadora tiene también sus límites, de tal forma que por mucho que mejoremos el procedimiento de votación por correo, siempre habrá personas que no pueden ejercer su sufragio ni por esta vía ni acercándose a la Mesa Electoral de su localidad, e igualmente siempre habrá deficiencias en la protección de los principios informadores del sufragio.

La clave radica en entender que el voto por correo no puede dar de sí más allá de un determinado límite. Es tan imposible convertirlo en

131 El envio de las papeletas electorales de las candidaturas electorales al domicilio de cada elector por parte de la OCE ya ha sido propuesta en el pasado por algunas fuerzas políticas, aunque no en relación con el voto por correo sino con la financiación electoral y la igualdad de oportunidades de los contendientes en las elecciones. En este sentido vid., por ejemplo, la enmienda presentada por el diputado Joseba Azkárraga Rodero, de Eusko Alkartasuna, durante la tramitación de la reforma de la LOREG de 1991 (Boletín Oficial de las Cortes Generales. Congreso de los Diputados, Serie A, núm. 46-3, de 6 de febrero de 1991, pág. 12; y Diario de Sesiones del Congreso de los Diputados, IV Legislatura, Pleno, núm. 88, de 14 de febrero de 1991, págs. 4360 y 4366.

132 Vid. los artículos 175, 193 y 227 de la LOREG, que regulan respectivamente las subvenciones electorales por mailing en las elecciones generales, locales y europeas. 
una vía efectiva de votación para todos los ciudadanos que no pueden votar directamente en su Mesa Electoral y asimilar, a la vez, sus condiciones de emisión a las del sufragio emitido directamente, como mezclar el agua y el aceite. Al igual que sucede en el fresco del genial Miguel Ángel en el que Adán no llega a tocar el dedo de Dios, el voto por correo no puede servir de complemento único del voto por personación e integrar armónicamente las condiciones básicas del sufragio. Basta con traer a colación una pregunta que seguramente se formulan con resignación y escepticismo muchos ciudadanos que votan por correo: ¿llegará este voto a su destino a tiempo de ser computado y sin ser manipulado por alguien?

La única posibilidad que se nos ocurre para hacer frente a este reto es la de superar la vía de la reforma del voto por correo y entrar directamente en el plano de la modificación total del sistema de votación en nuestro Derecho. Ya no se trata ahora -o no únicamente- de introducir determinadas mejoras en el procedimiento de votación por correo, sino lisa y llanamente de reducir su campo de aplicación y dar juego a otras vías de emisión de voto: el voto por personación en Mesas Electorales especificas 133 para los ciudadanos que estén fuera de su localidad, los residentes ausentes que viven en el extranjero, los que se hallen temporalmente fuera de España y los que se encuentren en centros de internamiento que tengan una mínima importancia 134; el voto a domicilio para los enfermos que se hallen en su domicilio o en hospitales con pocas camas; y el voto por procuración para los marineros embarcados en buques extranjeros o en buques españoles que no toquen puerto en España durante el proceso electoral y para los ciudadanos que residan o se hallen temporalmente en paises extranjeros en los que no haya consulados españoles, o estos queden geográfica-

133 No podemos extendernos en este momento sobre la forma de articular esta modalidad de votación, pero hay que tener presente que en la mayoría de los procesos electorales no es conveniente que las Mesas Electorales Especiales realicen el recuento de los votos recibidos, pues aparte de la extraordinaria complejidad de la tarea se puede poner en grave peligro el secreto del voto, habida cuenta la pertenencia de los votantes a circunscripciones distintas. El caso más Ilamativo sería el de las elecciones municipales dada la existencia de más de 8.000 municipios.

134 El establecimiento de Mesas Electorales en los consulados y embajadas españoles en el extranjero es una medida que se halla actualmente en estudio por una ponencia constituida en el seno de la Comisión Constitucional del Senado. Vid. Boletín Oficial de las Cortes Generales. Senado, Serie I, núm. 205, 19 de mayo de 2001, págs. 15-16. El Partido Popular es el más reticente, pero él propuso esta medida en 1991 (vid. la enmienda núm. 83 en el Boletín Oficial de las Cortes Generales. Congreso de los Diputados, Serie A, núm. 46-3, de 6 de febrero de 1991, pág. 30). 
mente muy apartados de su residencia. El voto por correo quedaría limitado a categorías muy concretas de ciudadanos, por ejemplo, los marineros embarcados en buques españoles que durante el período electoral atraquen en España o los soldados en misiones de paz en el extranjero.

Ésta es, sin embargo, una vía de actuación en la que ahora no podemos entrar en detalles. Es necesario hacerlo en un estudio especifico que posiblemente iniciemos próximamente, puesto que el objetivo merece la pena: la defensa de la pureza de la democracia. Lo dijo hace poco la diputada Consuelo Rumí a sus compañeros del Congreso de Ios Diputados:

«Señorías, existen aspectos de la democracia en los que la acción política no puede permitirse que los ciudadanos y las ciudadanas alberguen ninguna duda acerca de nuestras intenciones y de nuestras actitudes. Me refiero, como ustedes se pueden imaginar, a aquel momento que representa la máxima expresión de la soberanía popular y de la participación democrática de los ciudadanos en la vida pública. El ejercicio del derecho al voto constituye la manifestación concreta de la voluntad de los electores y para que sobre este acto no se pueda arrojar ninguna sombra, ya que de lo contrario los partidos políticos nos estaríamos jugando nuestra credibilidad democrática.... todos debemos reafirmar nuestro compromiso ineludible con las reglas del juego" 135 .

135 Vid. Diario de Sesiones del Congreso de los Diputados. VII Legislatura. Pleno, núm. 92, de 19 de junio de 2001, pág. 4499. 